Jacek SOBCZAK

Uniwersytet im. Adama Mickiewicza, Poznań

\title{
Dostęp do informacji publicznej - zagadka i parawan
}

$W_{\text {ne, a niedoceniane w praktyce znaczenie. W zakresie dostepu prasy }}^{\text {prowadzony do treści prawa prasowego art. 3a ma niezmiernie istot- }}$ do informacji publicznej zrównuje on bowiem prawa dziennikarza z prawami każdego podmiotu, który o takową informację może się ubiegać. Ustawodawca, nowelizując ustawę prawo prasowe nie pokusił się jednak o sprecyzowanie pojęcia ,informacja publiczna”, które używa w treści wspomnianego przepisu. W tej sytuacji, wyjaśnienia tego terminu należy szukać w tekście ustawy z 6 września 2001 r. o dostępie do informacji publicznej, która konkretyzuje wyrażone w art. 61 Konstytucji ogólne zasady korzystania z prawa do informacji. W art. 1 ust. 1 ustawy o dostępie do informacji publicznej (dalej: u.d.i.p) stwierdzono: „każda informacja o sprawach publicznych stanowi informację publiczną". Stwierdzenie to razi pleonazmem. Prawo do informacji sytuuje Konstytucja w art. $61 \mathrm{w}$ grupie wolności praw politycznych, co wydaje się konsekwencją związania jej z politycznymi prawami obywatelskimi. W literaturze zwraca się uwagę na wewnątrzkonstytucyjny kontekst prawa do informacji publicznej, podkreślając szczególne znaczenie ustrojowe tego prawa i wyjątkowo ścisły związek z interesem publicznym. W tej sytuacji zwraca się uwage na konieczność odczytywania przepisów gwarantujących prawo do informacji publicznej w powiązaniu z wolnościami i prawami pokrewnymi ${ }^{1}$.

Konstytucja nie precyzuje pojęcia ,informacja publiczna” i terminem tym się nie posługuje. Używa w art. 61 terminu ,informacja o działalności organów władzy publicznej oraz osób pełniących funkcje publiczne", akcentując w ten sposób kryteria podmiotowe. Prawo wyrażone w art. 61 Konstytucji jest konsekwencją i przesłanką zasady przejrzystości systemu

Zob. M. Jabłoński, K. Wygoda, Konstytucyjne uprawnienia jednostki w sferze informacyjnej, w: Sześć lat Konstytucji Rzeczypospolitej Polskiej. Doświadczenia i inspiracje, red. L. Garlicki, A. Szmyt, Warszawa 2003, s. 123. 
sprawowania władzy (jawności działania organów władzy publicznej) ustanowionej dla ujawnienia realizacji społecznej kontroli władzy i zapobiegania jej nadużyciom, przeciwdziałania korupcji urzędników oraz poprawiania jakości pracy administracji publicznej”. Prawo do informacji jest publicznym prawem podmiotowym, zapewniającym obywatelom możliwość żądania od organów władzy publicznej określonych informacji. Prawem tym, także ze względu na jego polityczny wymiar, objęte są jednak co do zasady wyłącznie informacje o charakterze publicznym, a więc przede wszystkim informacje o działalności władz publicznych, a warunkowo również informacje, które są w posiadaniu tych władz. Interpretacja zakresu przedmiotowego prawa do informacji publicznej powinna być bowiem ścisła i obejmować informacje relewantne w stosunku do natury prawa do informacji publicznej. Informacja o działalności osób pełniących funkcje publiczne jest informacją publiczną tylko w tym zakresie, w jakim wiąże się z pełnionymi przez te osoby funkcjami publicznymi, tj. działalnością publiczną. Związek ten musi być wyraźny i rzeczywisty, ale nie musi być bezpośredni. W zakresie przedmiotowym tego prawa mogą więc znaleźć się informacje dotyczące sfery życia osób pełniących funkcje publiczne, które objęte są konstytucyjnymi gwarancjami ochronnymi, np. prawa do ochrony życia prywatnego.

Zakres określonego w art. 61 Konstytucji prawa do informacji zdeterminowany jest w znacznej mierze przez samą Konstytucję. Przepisy jej określają bowiem, jakie uprawnienia wiążą się z obowiązywaniem tego prawa, oraz wskazuja, na jakie podmioty nałożony jest obowiązek podjęcia takich działań, aby to prawo obywatelskie mogło być zrealizowane. Prawo do uzyskania informacji dotyczy działalności organów władzy publicznej oraz osób pełniących funkcje publiczne, a także działalności organów samorządu gospodarczego i zawodowego oraz innych osób i jednostek organizacyjnych w zakresie, w jakim wykonują one zadania władzy publicznej i gospodarują mieniem komunalnym lub majątkiem Skarbu Państwa, oraz dostępu do dokumentów i wstępu na posiedzenia kolegialnych organów władzy publicznej pochodzących z publicznych wyborów, z możliwością rejestracji dźwięku lub obrazu. Nie jest jednak tak, że ustrojodawca, który całościowo uregulował bezpośrednio w samej Konstytucji zakres i granice tego prawa, wyłączył w tej materii dopuszczalność i potrzebę uzupełniających regulacji ustawowych. Mimo bowiem stosunkowo szerokiego unormowania bezpośrednio w Konstytucji prawa obywateli do dostępu do informacji, zarówno jeśli chodzi o krąg podmiotów obowiązanych zapewnić ten dostęp, jak i treść owych informacji, nie można 
wykluczyć, że i w tym zakresie zachodzi konieczność doprecyzowania - dookreślenia - zarówno cech i zakresu podmiotów obowiązanych do udzielenia informacji, jak i samej treści tej informacji i sposobu jej pozyskiwania. Nie można wykluczyć możliwości ingerencji w sferę życia prywatnego osób pełniących funkcje publiczne. Osoby te, ,ze względu na prawo obywateli do uzyskiwania informacji o działalności organów władzy publicznej, muszą się liczyć z obowiązkiem ujawnienia przynajmniej niektórych aspektów swego życia prywatnego. Nie ma jednak normy konstytucyjnej, która podobny ciężar nakładałaby na członków rodziny"2. Trybunał podkreślał też zarazem, że w ramach zderzenia się dwu wartości - z jednej strony konstytucyjnego prawa do informacji, z drugiej prawa do prywatności - nie można bezwzględnie przyznać priorytetu temu pierwszemu. Nie istnieje formuła ,zagwarantowania obywatelom dostępu do informacji za wszelką cenę"3. W przywołanym orzeczeniu Trybunał wprawdzie nie odniósł się wprost do kwestii wytyczenia granicy między sferą publiczną i prywatną, nie wykluczył jednak jednoznacznie możliwości ingerencji w tę ostatnią za pomocą instrumentu w postaci prawa do informacji publicznej. Podkreślono przy tym, że wykluczona jest nadmierna ingerencja $\mathrm{w}$ sferę życia prywatnego.

Używając w art. 61 terminu ,informacja o działalności organów władzy publicznej oraz osób pełniących funkcje publiczne", Konstytucja akcentuje $\mathrm{w}$ ten sposób kryteria podmiotowe. Z tego punktu widzenia, informacją publiczną jest informacja, która pozostaje w dyspozycji organu władzy publicznej - zarówno organów państwowych (publicznych), jak i samorządu terytorialnego. W tym zakresie ustawodawca nie wprowadził żadnych prawnych ograniczeń, aczkolwiek w praktyce, w zakresie dostępu do akt mogą one się pojawić w odniesieniu do takich organów władzy publicznej, posiadających informacje publiczne - jak sądy, prokuratury, organy policji i inne organy ścigania. Oczywiście, ograniczenie w dostępie do tych informacji podyktowane jest względami różnych tajemnic (np. tajemnicy postępowania przygotowawczego). Dostęp do akt sądowych limitowany jest przepisami kodeksu postępowania karnego, kodeksu postępowania cywilnego, regulaminu urzędowania sądów powszechnych oraz regulaminu Sądu Najwyższego. Z racji informacji zawar-

2 Zob. wyrok Trybunału Konstytucyjnego z 13 lipca 2004 r., K 20/03, OTK ZU 2004, nr 7, poz. 63 .

3 Zob. wyrok Trybunału Konstytucyjnego z 19 czerwca 2002 r., K 11/02, OTK ZU 2002, nr 4/A, poz. 43. 
tych w aktach sądowych - częstokroć bardzo „wrażliwych”, a odnoszących się nie tylko do oskarżonych, stron postępowania, lecz także świadków, pokrzywdzonych itd. - trudno opowiedzieć się za szerokim dostępem do takowych akt i należy przyjąć, że w tym zakresie prawo do informacji publicznej jest ograniczone przez przepisy szczegółowe, zarówno w odniesieniu do dziennikarzy, jak i ,zwykłych” obywateli. Osobami pełniącymi funkcje publiczne są niewątpliwie wszyscy funkcjonariusze publiczni w rozumieniu art. $115 \S 13$ k.k. - a oprócz nich, także osoby wypełniające funkcje organów władzy publicznej przez gospodarowanie mieniem komunalnym lub majątkiem Skarbu Państwa. Warto pamiętać, że z pojęciem „funkcjonariusz publiczny” prawo karne łączy z jednej strony odpowiedzialność karną - stosownie do pełnionej funkcji publicznej, z drugiej strony, szczególną ochronę prawnokarną - w przypadku narażenia jego czci i godności w czasie wykonywania funkcji.

Ustalenie kwestii zakresu terminologicznego określenia „osoba pelniąca funkcje publiczne" ma znaczenie nie tylko dla ustalenia zakresu podmiotowego konstytucyjnego prawa do informacji określonego w art. 61 Konstytucji oraz jego związków z odpowiednimi przepisami ustawy o dostępie do informacji publicznej i dalej - z treścią art. 3a pr.pr., lecz także dla kwestii, o jakich mowa w art. 14 ust. 6 pr.pr. Wypada także zauważyć, że w treści ostatniego z tych przepisów mowa o publikacji danych dotyczących prywatnej sfery życia, których nie wolno publikować - „chyba, że wiąże się to bezpośrednio z działalnością publiczną danej osoby”. Określenie „działalność publiczna” nie jest przy tym definiowane w treści prawa prasowego, natomiast mowa o niej w tekście $\S 19$ art. 115 k.k. in fine. W ujęciu tego ostatniego przepisu, „osobą pełniącą funkcję publiczną” jest także inna osoba, poza wymienionymi wcześniej w treści tego przepisu, „której uprawnienia i obowiązki w zakresie działalności publicznej są określone lub uznane przez ustawę lub wiążącą Rzeczpospolitą Polską umowę międzynarodową". W tej sytuacji pojęcie „działalność publiczna” ma niewątpliwie szerszy zakres od określenia „funkcja publiczna”. Obu wspomnianych określeń nie wolno jednak mylić z występującym na gruncie prawa autorskiego terminem „osoba powszechnie znana”. Osoba powszechnie znana to osoba, która może być funkcjonariuszem publicznym, może pełnić funkcję publiczną, może też zajmować się działalnością publiczną w rozumieniu $\S 19$ art. 115 k.k. Osobą powszechnie znaną może być aktor, uczony, duchowny, podróżnik, dziennikarz, którego osoba jest rozpoznawana przez mniejsze lub większe grono obywateli, a którego dokonania są znane publiczności. $\mathrm{Z}$ pewnymi wahaniami do tego grona 
można zaliczyć znanych przestępców, pamiętając jednak o ograniczeniach, jakie nakłada kodeks postępowania karnego przy publikacji ich wizerunków. Pojęcie „osoby powszechnie znanej” wymaga relatywizacji. W małym mieście taką osobą może być burmistrz, komendant posterunku policji, proboszcz, kierownik sklepu mięsnego. Dlatego też, publikacje wizerunku takich osób w lokalnych środkach społecznego przekazu są z mocy art. 81 ust. 2 pkt 1 p.a.p.p. - oczywiście pod warunkiem, że wizerunek ten został wykonany w związku $\mathrm{z}$ pełnieniem przez taką osobę funkcji publicznych, w szczególności: politycznych, społecznych, zawodowych. Publikacja tego samego wizerunku w środkach przekazu o zasięgu ogólnopolskim jest niedopuszczalna $\mathrm{z}$ tej racji, że nie będzie to już wizerunek osoby powszechnie znanej.

Nie może natomiast budzić wątpliwości, że osoby bliskie jednostkom, o jakich mowa w art. 61 ust. 1 Konstytucji (ich małżonkowie, krewni i powinowaci), nie są osobami pełniącymi funkcje publiczne. Nawet uzasadniona ingerencja $\mathrm{w}$ sferę życia prywatnego osoby publicznej pełniącej funkcję publiczną nie może prowadzić do naruszenia prawa do prywatności osób trzecich, w tym członków jej rodziny. Zgodzić się należy ze stanowiskiem wyrażonym przez Trybunał Konstytucyjny, że „samo ujawnienie pokrewieństwa, czy jego braku, w pewnych sytuacjach może naruszać prywatność zarówno funkcjonariusza, jak i osoby mu bliskiej (np. w przypadku dzieci pozamałżeńskich, przyrodniego rodzeństwa, wychowywania dziecka, którego funkcjonariusz nie jest rodzicem). Informowanie przez funkcjonariusza o zdarzeniach z życia rodzeństwa, wnuków itd. może być źródłem konfliktów rodzinnych, w szczególności wtedy, gdy członkowie rodziny funkcjonariusza dochodzą do pewnych dóbr czy pozycji wyłącznie własnym wysiłkiem. Publiczne wiązanie ich osiągnięć $\mathrm{z}$ faktem pozostawania $\mathrm{w}$ związkach rodzinnych $\mathrm{z}$ funkcjonariuszem może być odczytane jako dyskredytowanie ich własnej pozycji, czy wręcz - może być upokarzające. Zdarzają się też przypadki, gdy nabycie mieszkania, podjęcie pracy w określonej miejscowości - pośrednio ujawniają sytuację rodzinną czy plany życiowe danej osoby (np. separację, rozwód, czy - przeciwnie - zamiar zawarcia związku małżeńskiego). Podawanie do publicznej wiadomości informacji wymaganych przez kwestionowane przepisy może więc naruszać prywatność osób niepełniących funkcji publicznych"4.

${ }^{4}$ Zob. wyrok Trybunału Konstytucyjnego z 13 lipca 2004 r., K 20/03, OTK ZU nr 7/A/2004, poz. 63 . 
Z punktu widzenia przedmiotowego, informacja publiczna to informacja urzędowa, administracyjna. Przez informację administracyjną rozumie się wszelką informację pozostającą w dyspozycji administracji ${ }^{5}$. Rzuca się przy tym w oczy brak korelacji między treścią art. 61 ust. 1 Konstytucji a art. 1 ust. 1 u.d.i.p. O ile Konstytucja akcentuje kryterium podmiotowe wskazując na prawa obywatela, o tyle w ustawie na plan pierwszy wybija się pojęcie informacji publicznej mające charakter przedmiotowy. Warto zauważyć, iż pewną pomocą dla określenia zakresu informacji publicznej wydaje się być dyspozycja art. 6 ust. 1 u.d.i.p., przy czym pamiętać należy, że zawarte $\mathrm{w}$ tym przepisie wyliczenie nie ma charakteru enumeratywnego.

Do informacji publicznej ustawodawca zaliczył pięć kategorii, przy czym w odniesieniu do każdej z nich starał się wskazać pola należące do takich informacji. Tak więc, informacją publiczną są informacje: o polityce wewnętrznej i zagranicznej; o podmiotach zobowiązanych do udostępniania informacji publicznej, a wyliczonych w treści art. 4 ust. 1 u.d.i.p. o zasadach funkcjonowania tych podmiotów; o danych publicznych; wreszcie - o majątku publicznym. Należy pamiętać, że do podmiotów zobowiązanych do udostępniania informacji publicznej w myśl art. 4 ustawy należą władze publiczne oraz inne podmioty wykonujące zadania publiczne, w tym w szczególności: organy władzy publicznej, organy samorządów gospodarczych i zawodowych, podmioty reprezentujące zgodnie z odrębnymi przepisami Skarb Państwa, podmioty reprezentujące państwowe osoby prawne albo osoby prawne samorządu terytorialnego, podmioty reprezentujące inne państwowe jednostki organizacyjne albo jednostki organizacyjne samorządu terytorialnego, wreszcie - podmioty reprezentujące inne osoby lub jednostki organizacyjne, które wykonują zadania publiczne lub dysponują majątkiem publicznym oraz osoby prawne, w których Skarb Państwa, jednostki samorządu terytorialnego lub samorządu gospodarczego albo zawodowego mają pozycję dominującą w rozumieniu przepisów o ochronie konkurencji i konsumentów. Zobowiązane do udostępniania informacji publicznych są także związki zawodowe i ich organizacje oraz partie polityczne.

Zamiarem ustawodawcy było niewątpliwie względnie szerokie określenie podmiotów zobowiązanych do udostępnienia informacji publicz-

Zob. W. Sokolewicz, Komentarz do art. 61 Konstytucji Rzeczypospolitej Polskiej, op. cit., s. 21; T. Górzyńska, Prawo do informacji i zasada jawności administracyjnej, Kraków 1999, s. 15. 
nej. Ustawodawca wskazał na władze publiczne jako na zobowiązane do udzielania tych informacji, nie dokonując szczegółowej specyfikacji tych organów. Pojawić się musi pytanie, czy określenie „władze publiczne” i „organy władzy publicznej” należy odnosić do pojęcia „administracja publiczna" - innymi słowy, czy organy władzy publicznej to organy administracji publicznej. Samo pojęcie „administracja publiczna” wydaje się dość sporne. W literaturze podkreśla się, że administrację publiczną można zdefiniować z uwagi na funkcje, jakie sprawuje, uznając jej działania za proces stosowania określonych reguł, czyli przekształcania ogólnych przepisów w konkretne decyzje dotyczące indywidualnych spraw ${ }^{6}$. Definicja ta wydaje się zbyt szeroka i administracja tak zdefiniowana może wywoływać wątpliwości, co do swojego zakresu, gdyż organy sądowe także przekształcają ogólne procesy w konkretne decyzje.

$\mathrm{Z}$ punktu widzenia przedmiotowego, administracja publiczna zajmuje się strukturami władzy politycznej, których podstawowym zadaniem jest realizacja funkcji polegających na przekształcaniu ogólnych procesów w konkretne decyzje ${ }^{7}$. W polskiej nauce prawa administracyjnego zakres administracji publicznej ustalił T. Bigo stwierdzając, że administracja publiczna $\mathrm{w}$ znaczeniu podmiotowym obejmuje administrację państwową, związki publiczno-prawne (terytorialne i korporacyjne) oraz inne podmioty stosujące przymus bezpośredni ${ }^{8}$. Do takiego rozumienia administracji publicznej wyraźnie nawiązuje E. Ochendowski, zauważając, że administracja publiczna jest sprawowana przez państwo w najszerszym tego słowa znaczeniu - a więc przez organy państwowe, związki publiczno-prawne, związki samorządowe i inne podmioty administracji. $\mathrm{W}$ tym ujęciu administracją publiczną w sensie materialnym przedmiotowym, jest taka działalność państwa, której przedmiotem są sprawy administracyjne, albo inaczej-zadania i kompetencje władzy wykonawczej.

W rozumieniu formalnym administracją publiczną jest cała działalność wykonywana przez podmioty administracji, bez względu na to, czy ma ona charakter administracyjny, czy też nie. Z punktu widzenia organizacyjnego (podmiotowego) - według tej koncepcji - administracja publiczna to ogół podmiotów administracji, a więc organy administracji

6 Zob. B. G. Peters, Administracja publiczna w systemie politycznym, Warszawa 1999, s. 16.

7 Zob. B. G. Peters, Administracja..., s. 16.

8 T. Bigo, Zwiazki publiczno-prawne w świetle ustawodawstwa polskiego, Warszawa 1928, s. 210. 
i inne podmioty wykonujące określone funkcje z zakresu administracji publicznej. Tak więc, administracja to działalność państwa, która nie wykazuje cech ustawodawstwa, ani sądownictwa ${ }^{9}$. Zwolennicy tego ujęcia powoływali się zwykle na treść nieobowiązującej już ustawy z 11 maja 1995 r. o Naczelnym Sądzie Administracyjnym, gdzie w art. 20 ust. 2 stwierdzono, iż „organami administracji publicznej [...] są naczelne i centralne organy administracji państwowej, terenowe organy administracji rządowej, organy samorządu terytorialnego oraz inne organy w zakresie, $\mathrm{w}$ jakim zostały powołane z mocy prawa do załatwiania spraw z zakresu administracji publicznej" 10 . Obecnie obowiązujący kodeks postępowania administracyjnego w art. $5 \S 2$ pkt $3 \mathrm{w}$ zw. $z$ art. 1 pkt 1 i 2 , mówiąc nie tyle o administracji publicznej, ile o jej organach, stwierdza, że przez organy administracji publicznej należy rozumieć: ministrów, centralne organy administracji rządowej, wojewodów, działające w ich lub we własnym imieniu inne terenowe organy administracji rządowej (zespolonej i niezespolonej), organy jednostek samorząqu terytorialnego oraz organy administracji właściwe $\mathrm{w}$ sprawach indywidualnych rozstrzyganych w drodze decyzji administracyjnych, wreszcie - inne organy państwowe oraz inne podmioty, które są powołane z mocy prawa lub na podstawie porozumień do załatwiania takich spraw ${ }^{11}$. W literaturze podkreśla się, że pojęcie organu administracji publicznej określone w art. $5 \S 2$ pkt 3 k.p.a. ma charakter konwencjonalny, ,ponieważ w doktrynie prawa administracyjnego jest ono używane w znacznie węższym znaczeniu i w żadnym razie nie obejmuje ono podmiotów wykonujących zlecone funkcje z zakresy administracji publicznej”. Zwraca się przy tym uwage, że pozycja prawna „naczelnych organów administracji państwowej jest w doktrynie i strukturze administracji wyraźnie oddzielona od niżej stojących w hierarchii centralnych organów administracyjnych, jednakże z punktu widzenia toku instancji, organy te zostały ze sobą zrównane w art. $5 \S 2$ pkt 4 k.p.a. W tej sytuacji, mając na względzie, iż bezspornym wydaje się w doktrynie, że do administracji publicznej nie należy ustawodawstwo i sądownictwo,

9 Zob. E. Ochendowski, Prawo administracyjne. Częśś ogólna, Torun 2002, s. $18-22$.

10 Dz. U. 1995, Nr 74, poz. 368 z późn. zm. Treść art. 20 ust. 2 w kształcie nadanym przez art. 19 pkt 3 ustawy z dnia 29 grudnia 1998 r. o zmianie niektórych ustaw w związku z wdrożeniem reformy ustrojowej państwa Dz. U. 1998, Nr 162, poz. 1126 , z dniem 1 stycznia 1999 r.

11 Dz. U. 2000, Nr 98, poz. 1071. 
trzeba opowiedzieć się przeciwko prezentowanej w literaturze tezie, że ustawodawca zamierzał objąć zasięgiem ustawy o dostępie do informacji publicznej Sejm i Senat oraz sądy"12.

Niektórzy przyjmują że administrację publiczną w znaczeniu podmiotowym tworzą organy państwa, organy samorządu terytorialnego oraz zakłady administracyjne, a także inne podmioty, które wykonują funkcje zlecone administracji publicznej ${ }^{13}$. J. Boć do podmiotów administracji publicznej zalicza: organy administracji rządowej (państwowej), organy przedsiębiorstw realizujących zadanie administracyjne, organy społeczne wykonujące funkcje administracji publicznej oraz podmioty prywatne (osoby fizyczne) wykonujące funkcje administracji publicznej ${ }^{14}$. Wśród definicji mieszanych przedmiotowo-podmiotowych wskazać należy definicję H. Izdebskiego i M. Kuleszy, którzy pod pojęciem ,administracja publiczna” chcą rozumieć „zespół działań, przedsięwzięć organizatorskich i wykonawczych, prowadzonych na rzecz realizacji interesu publicznego, przez różne podmioty, organy i instytucje, na podstawie ustawy i w określonych prawem formach" ${ }^{\text {". }}$. Przyjęcie, że administracja publiczna nie obejmuje ustawodawstwa i sądownictwa wyłączałoby działalność władz ustawodawczych i sądowniczych spod zakresu działania art. 4 u.d.i.p.

Nie oznacza to oczywiście, że Sejm i Senat oraz sądy nie są zobowiązane do udzielania informacji publicznej. Obowiązek takowy na nich spoczywa, ale nie w oparciu o ustawę o dostępie do informacji publicznej. Wynika on z treści art. 61 Konstytucji i konkretyzowany jest w odniesieniu do Sejmu i Senatu przez stosowne punkty regulaminu, a w odniesieniu do sądów - przez regulacje kodeksowe. Objęcie sądów, a także Sejmu i Senatu rozporządzeniem Ministra Spraw Wewnętrznych i Administracji z dnia 17 maja 2002 r. w sprawie Biuletynu Informacji Publicznej wydaje się wynikać z błędnego odczytania dyspozycji art. 4 u.d.i.p. Objęcie tych organów działaniami Ministra Spraw Wewnętrznych i Administracji - w zakresie bądź co bądź organizacyjnym, jakim jest dostęp do informacji publicznej - z natury rzeczy narusza zagwarantowany w art. 10 ust. 1

12 Zob. M. Jabłoński, K. Wygoda, Ustawa o dostępie do informacji publicznej. Komentarz, Wrocław 2002, s. 47.

13 Zob. J. Jeżewski, Administracja publiczna, w: Encyklopedia prawa, red. U. Kalina-Prasznic, s. 5.

14 Zob. Prawo administracyjne, red. J. Boć, Wrocław 1998, s. 116 i n.

15 Zob. H. Izdebski, M. Kulesza, Administracja publiczna. Zagadnienia ogólne, wyd. II, Warszawa 1999, s. 79. 
Konstytucji trójpodział władz. Za taką supozycją przemawia także i to, że jak zauważono wyżej - w praktyce dostęp do informacji publicznej będącej w dyspozycji sądów z natury rzeczy jest ograniczony przepisami kodeksów: postępowania karnego, cywilnego i administracyjnego. Dodatkowo rozumowanie to wzmacnia fakt, że zasady udzielania informacji publicznej przez Sejm i Senat określają ich regulaminy. W literaturze podkreśla się, że jest to wyjątkowe odstępstwo od reguły ustawowego określania trybu udzielania informacji publicznej ${ }^{16}$.

Prawo prasowe nie definiuje pojęcia ,informacji”. W języku potocznym informacja to wiadomość, komunikat, wskazówka, pouczenie ${ }^{17}$. Ustawodawca wydaje się używać pojęcia ,informacja” w dwóch pierwszych, wskazanych wyżej, potocznych znaczeniach tego słowa. W literaturze podkreśla się, że informacją publiczną jest każda informacja - ale tylko o sprawach publicznych i to tylko taka, która znajduje się w posiadaniu podmiotu będącego adresatem żądania. Udostępniając informację, każdorazowo należy rozważyć prawdopodobieństwo naruszenia przepisów ustawowych zabraniających ich ujawnienia - i to w zakresie informacji niejawnych oraz innych dóbr podlegających ochronie (np. prywatności). Wśród stanowisk doktryny należy odnotować pogląd, sprowadzający się do przeciwstawienia informacji publicznej pojęciu ,informacja niejawna", co prowadzi do utożsamienia informacji publicznej z ,upublicznioną". W tej sytuacji informacja publiczna stanowi pojęcie szersze od informacji uzyskanej z dokumentów urzędowych. Wychodząc z tego założenia, stwierdza się w literaturze, że każda informacja o sprawach publicznych także niejawna i objęta tajemnicą na mocy innych ustaw - jest informacją publiczna, w danym momencie nieobjętą prawem dostępu. Tak więc, zbiór informacji publicznych dzieli się dychotomicznie według cech kontradyktoryjnych na jawne - i z tego tytułu dostępne - oraz niejawne - chronione szczególnymi tajemnicami, a więc niedostępne w trybie ustawy ${ }^{18}$. Skoro informacją publiczną jest informacja pozostająca w posiada-

16 Zob. A. Bałaban, Opinie w sprawie interpretacji art. 61 Konstytucji z 2 kwietnia 1997 r., „Przegląd Sejmowy” 1999, nr 6, s. 69; W. Sokolewicz, Komentarz do art. 61 Konstytucji Rzeczypospolitej Polskiej, op. cit., s. 44; Konstytucja Rzeczypospolitej Polskiej oraz komentarz do Konstytucji RP z 1997, red. J. Boć, Wrocław 1998, s. 115.

17 Słownikjęzyka polskiego, red. M. Szymczak, Warszawa 1988, t. 1, s. 788.

18 Zob. H. Izdebski, Ustawa z 6 września 2001 o dostępie do informacji publicznej. Komentarz, w: Dostęp do informacji publicznej. Wdrażanie ustawy, red. H. Izdebski, Warszawa 2001, s. 25-26. 
niu władz publicznych i dotycząca spraw publicznych, to takowa informacja, która jest wprawdzie w posiadaniu władz publicznych, ale nie dotyczy spraw publicznych, lecz innych - a więc prywatnych - nie jest informacją publiczną. W konsekwencji, nie można uznać za sprawy publiczne (a więc za informację publiczna) spraw prywatnych, w tym: danych osobowych, informacji o życiu prywatnym i rodzinnym, a także takich, które naruszałyby dobra osobiste w postaci godności lub czci.

Warto zauważyć, że w ustawie wyraźnie wskazano, iż jej przepisy nie naruszają rozwiązań zawartych $\mathrm{w}$ innych ustawach określających odmiennie zasady i tryb dostępu do informacji będących informacjami publicznymi. W uzasadnieniu projektu ustawy wskazano, że przepisami takimi, których ustawa nie chce naruszać są przepisy: kodeksu postępowania administracyjnego, ordynacji podatkowej, dotyczące rejestrów sądowych i publicznego dostępu do informacji. W literaturze zwraca się uwagę, że ustawa o dostępie do informacji publicznej nie obejmuje treści dotyczących dostępu do informacji: o środowisku i jego ochronie, o finansach publicznych, o gospodarce finansowej samorządu terytorialnego, o toczącym się postępowaniu sądowym, o zamówieniach publicznych. Nie wskazano jednak przyczyn tych supozycji, a praktyka Naczelnego Sądu Administracyjnego zdaje się wskazywać na tendencje do obejmowania zakresem działania ustawy wszystkich sfer życia ${ }^{19}$. Pogląd, że do informacji o toczących się postępowaniach sądowych nie stosuje się przepisów ustawy o dostępie do informacji publicznej, lecz uregulowania zawarte w odpowiednich kodeksach postępowania, podbudowuje sformułowaną powyżej tezę, iż sądownictwo nie należy do organów administracji publicznej, sądy nie są organami administracji publicznej ani organami władzy publicznej, a informacje o toczących się tam sprawach nie mogą być udzielane w trybie ustawy o dostępie do informacji publicznej.

Gwarancje konstytucyjne dotyczące prawa dostępu do informacji (art. 61) nie mogą być w pełni utożsamione z prawem określonym w art. 54 Konstytucji, zapewniającym wolność wyrażania poglądów oraz pozyskiwania i rozpowszechniania informacji. Zakresy tych przepisów częściowo się krzyżują jednakże wolność pozyskiwania i rozpowszechnienia informacji jest ujęta szerzej niż prawo z art. 61 Konstytucji. Nie każda bowiem informacja, która zgodnie z wolnością ujętą w art. 54 Konstytucji może być

19 Zob. H. Izdebski, Ustawa z 6 września 2001 o dostępie do informacji, op. cit., s. 28-29. 
pozyskana i rozpowszechniona, w tym także odnosząca się do sfery prywatnej osoby, może być uznana za informację, co do której istnieje po stronie danego organu władzy publicznej obowiązek ujawnienia, skonkretyzowany w ustawie o dostępie do informacji. Pewne informacje istotne np. z punktu widzenia interesu społecznego, a dotyczące sfery życia prywatnego osoby publicznej, mogą być bowiem ujawnione także wtedy, kiedy nie pozostają $\mathrm{w}$ związku z pełnieniem funkcji, ale mają znaczenie dla oceny zachowań danej osoby, jej wiarygodności i prezentowanych publicznie poglądów. Art. 61 Konstytucji dotyczy natomiast jedynie pewnego „wycinka” prawa do pozyskiwania informacji, którego korelatem jest zawsze obowiązek ujawnienia istniejący po stronie odpowiedniego organu władzy publicznej. Obowiązek ten nie rozciaga się więc na wszelkie dane osobowe osoby pełniącej funkcję publiczną, a jedynie te, które pozostają w związku z pełnieniem funkcji. W tym sensie można więc mówić jedynie o pewnej komplementarności obu analizowanych regulacji konstytucyjnych.

W literaturze uważa się, że prawo do wolności informacji należy do podstawowych praw człowieka i stanowi część prawa do wolności wypowiedzi. Niemniej, w ujęciu Konstytucji RP prawo to przysługuje jedynie obywatelowi. Krytykę tego rozwiązania w sposób przekonujący przeprowadza M. Mucha dowodząc, że wyrażone w art. 61 Konstytucji prawo do informacji jest w gruncie rzeczy szczególnym rodzajem prawa do informacji określonego w art. 54 Konstytucji, które przysługuje nie tylko obywatelowi, ale każdemu. Wskazuje ona, że „ograniczenia prawa do uzyskiwania informacji o działalności podmiotów wymienionych w treści art. 61 Konstytucji pozbawia prawa do informacji o działalności tych podmiotów osoby, które nierzadko faktycznie znajdują się w zasięgu tej władzy, podlegająjej działaniom”. Zauważa też, że w płaszczyźnie międzynarodowej, prawa do informacji zdają się przysługiwać każdej osobie, a już na pewno - obywatelom państw Rady Europy bądź Unii ${ }^{20}$. W praktyce uznaje się, że chociaż kategoria obywatelstwa odnosi się wyłączne do osoby fizycznej, to przez obywatela w rozumieniu art. 61 ust. 1 Konstytucji, należy rozumieć także podmiot zbiorowy ${ }^{21}$. Warto podkreślić, że prawo prasy (wydawcy, nadawcy), jako zbiorowego podmiotu prawa do informacji

20 M. Mucha, Obowiazki administracji publicznej w sferze dostępu do informacji, Wrocław 2002, s. 58-59, 248-249.

21 Zob. M. Jaśkowska, Dostęp do informacji publicznej w orzecznictwie Naczelnego Sąu Administracyjnego, Toruń 2002, s. 41-42. 
w rozumieniu art. 61 ust. 2 Konstytucji, który znajduje konkretyzację w treści art. 3a pr.pr., jest realizowane poprzez indywidualnie wykonywane czynności przez dziennikarzy, działających w imieniu wydawcy lub nadawcy. To dziennikarz dla pozyskania informacji publicznej wykorzystuje dostęp do dokumentów oraz prawo wstępu na posiedzenia kolegialnych organów władzy publicznej. Uznając, iż prawo do informacji, o jakim mowa w art. 61, mimo literalnego brzmienia tego przepisu dotyczy każdego i jest prawem człowieka, to trudno wymagać od dziennikarza domagającego się takiej informacji, aby udowodnił, że jest obywatelem polskim. Trudno także uznać, że wspomniane prawa prasy przysługują tylko tytułom bądź nadawcom, którzy mają swoją siedzibę w Polsce. Ewentualne względy na bezpieczeństwo państwa, tajemnicę państwową, służbową i inną tajemnicę chronioną ustawą i tak każdorazowo mogą ograniczyć dostęp do informacji publicznej.

W literaturze, niezbyt dokładnie odczytując uzasadnienie orzeczenia Trybunału Konstytucyjnego ${ }^{22}$, wyrażono błędny pogląd, że prawo do informacji wydawcy bądź nadawcy jest prawem podmiotu zbiorowego ${ }^{23}$. W istocie rzeczy Trybunał Konstytucyjny stwierdził wręcz odwrotnie, podkreślając, że prawo podmiotowe „może obywatel realizować osobiście, jak też to prawo może się urzeczywistniać za pośrednictwem prasy. Wynika z tego, że skarga konstytucyjna zmierzająca do ochrony prawa do informacji przysługuje zarówno każdemu obywatelowi, jak też i «prasie», a konkretnie - odpowiedniemu organowi prasowemu”. Warto zauważyć, że w myśl art. 7 ust. 2 pkt 1 pr.pr. ,prasa obejmuje również zespoły ludzi i poszczególne osoby zajmujące się działalnością dziennikarską". W tej sytuacji, ,prasą" jest każdy dziennikarz, tak więc art. 3a pr.pr. dotyczy zarówno podmiotu zbiorowego, jak i każdego dziennikarza, który jest ,prasą”. Odmienna interpretacja stawiałaby poza zakresem ,prasy” wszystkich tych dziennikarzy, którzy nie są związani z żadnym tytułem prasowym, ani z żadnym wydawcą.

Rozważania te w gruncie rzeczy mają charakter jedynie porządkujący i teoretyczny, gdyż ustawodawca nie uprzywilejowuje w żaden sposób dziennikarzy w zakresie dostępu do informacji publicznej i - jak się wydaje - nie widzi podstaw, aby dziennikarze mogli mieć dostęp do tako-

22 Zob. postanowienie Trybunału Konstytucyjnego z 13 września 2000 r., SK 4/00 OTK ZU nr 6, poz. 193.

23 Zob. W. Sokolewicz, Komentarz do art. 61 Konstytucji Rzeczypospolitej Polskiej, op. cit., s. 17. 
wych informacji na innych zasadach niż zwykli obywatele. W literaturze zgłasza się jednak postulaty ułatwienia dziennikarzom dostępu do informacji publicznej poprzez akredytację i udzielanie informacji zastrzeżonych $\mathrm{z}$ uwagi na dobra osobiste funkcjonariuszy publicznych ${ }^{24}$. Wszelkie jednak przywileje w tym zakresie winny przybrać określony kształt prawny. W literaturze jednoznacznie stwierdzono, że od obywatela, a więc i od dziennikarza domagającego się informacji publicznej nie wolno żądać wykazania interesu prawnego bądź faktycznego, ani też - ujawnienia celu, dla którego ubiega się o informację. Podobnie, niedopuszczalne jest żądanie, aby ubiegający się o informacje wyraził zgodę na przetwarzanie jego danych osobowych ${ }^{25}$. Oczywiście łączy się to po stronie organu udzielającego informacji z obowiązkami ochrony imiennych danych osobowych, zwłaszcza tzw. danych ,wrażliwych”.

Mimo, że - jak podnosi się w doktrynie - kontekst międzynarodowy prawa do informacji jest ubogi poza regulacjami odnoszącymi się do wolności informacji w ogólności ${ }^{26}$, warto zwrócić uwagę na fakt, iż liczne dokumenty organizacji międzynarodowych od lat statuowały prawo do informacji jako jedno z podstawowych praw bądź wolności przysługujących każdemu człowiekowi, łącząc je częstokroć ściśle z prawem do ochrony danych osobowych $^{27}$. Wśród dokumentów Rady Europy należy zwrócić uwagę na uchwalone zalecenie nr 582 z 23 czerwca 1970 r. w sprawie środków komunikacji masowej, w którego treści zaakcentowano wolność poszukiwania informacji i ciążący na władzach publicznych obowiązek komunikowania informacji dotyczących kwestii publicznych. W dziewięć lat później Zgromadzenie Parlamentarne Rady Europy przyjęło zalecenie nr 854

24 Zob. E. Kulesza, Obywatel musi mieć dostęp do informacji, „Rzeczpospolita”, 25 kwietnia 2000, s. C2; M. Fazan, Projekty ustaw o dostęie do informacji nie maja szans na uchwalenie, „Prawo i Życie” 2001, nr 1, s. 47.

25 A. Lipiński, Prawo powszechnego dostępu do informacji o środowisku, PiP 2001, z. 9, s. 67; B. Kudrycka, S. Iwanowski, Prawo obywatela do informacji o działaniach organów administracji publicznej, PiP 1999, z. 8, s. 78.

26 Zob. art. 19 Powszechnej Deklaracji Praw Człowieka z 1948 r., art. 19 Międzynarodowego Paktu Praw Obywatelskich i Politycznych z 1966 r., art. 10 Europejskiej Konwencji o Ochronie Praw Człowieka i Podstawowych Wolności z 1950 r., art. 11 Karty Praw Podstawowych Unii Europejskiej.

27 Zob. W. Sokolewicz, Komentarz do art. 61 Konstytucji Rzeczypospolitej Polskiej, op. cit., s. 11; T. Górzyńska, Geneza i rozwój prawa do informacji, w: Współczesne problemy samorzqdu terytorialnego - dostęp do informacji publicznej, red. A. Drogoń, „Miscellanea Iuridica” 2004, t. 4, s. 126 i n.; tejże, Prawo do informacji a zasada jawności administracyjnej, Kraków 1999, s. 38-87. 
(skierowane do Komitetu Ministrów Rady Europy) w sprawie powszechnego dostępu do dokumentów rządowych i wolności informacji. W treści wspomnianego zalecenia zalecono Komitetowi, aby podjął środki zachęcające państwa członkowskie do wprowadzenia ustaw regulujących sprawę wolności informacji.

Sformułowanie art. 61 ust. 1 Konstytucji stanowi więc nawiązanie do długiej historii rozwoju prawa regulującego dostęp do informacji publicznej. Wydana 25 listopada 1981 r. dyrektywa Komitetu Ministrów Rady Europy nr R(81)19 w sprawie dostępu do informacji posiadanej przez władze publiczne sformułowała osiem podstawowych zasad: na obszarze państw członkowskich każdy ma prawo do otrzymywania informacji znajdującej się w posiadaniu władzy publicznej; prawo to ma być w sposób skuteczny zagwarantowane; brak interesu prawnego nie może stanowić powodu odmowy dostępu do informacji; dostęp do informacji jest równy; ograniczenia w dostępie do informacji mogą wynikać jedynie z konieczności ochrony uzasadnionego interesu publicznego oraz interesu jednostki w przypadku informacji bezpośrednio jej dotyczących; żądanie udzielenia informacji musi być rozpatrzone w rozsądnym terminie; odmowa udzielenia informacji musi być wyczerpująco uzasadniona i będzie mogła być skontrolowana. Podkreśla przy tym, że dostęp do informacji publicznej leży również w interesie tych władz. Gwarancje prawa dostępu do informacji mają przyczyniać się do pełnego informowania społeczeństwa o wszystkim, co dotyczy życia publicznego.

Ze wspomnianymi aktami wiążą się dokumenty Rady Europy chroniące prawa do wolności informacji w postępowaniu administracyjnym. Wśród nich wskazać należy na: uchwałę nr (77) 31 Komitetu Ministrów Rady Europy z 28 września 1977 r. o ochronie jednostki wobec aktów administracji oraz zalecenie nr R (80) 2 Komitetu Ministrów Rady Europy z 11 marca 1980 r. dotyczące wykonywania przez administrację władzy dyskrecjonalnej. Liczne akty normatywne, zarówno Rady Europy, jak i Unii Europejskiej dotyczą ochrony danych osobowych. W zaleceniu Komitetu Ministrów Rady Europy nr R (91) 10 z 9 września 1991 r. w sprawie udostępniania osobom trzecim danych osobowych pozostających w posiadaniu władz publicznych zwraca się uwagę na to, że wolność dostępu do informacji i ochrona danych osobowych nie muszą pozostawać ze sobą w sprzeczności, celem ochrony danych osobowych nie jest bowiem a priori ustanowienie ograniczeń $\mathrm{w}$ swobodzie przepływu informacji w społeczeństwie, lecz określenie warunków przetwarzania tych danych. Możliwość udostępniania danych osobowych musi być powiązana z gwa- 
rancjami poszanowania życia prywatnego osób, których dane te dotyczą. Stwierdza się dalej, że udostępnianie danych jest dopuszczalne, o ile zezwala na to ustawa szczególna lub jeśli dane są publicznie dostępne w świetle przepisów regulujących dostęp do informacji w sektorze publicznym. Podkreśla się też brak konieczności uzasadniania wniosku o udostępnienie danych osobowych oraz fakt, że władze nie powinny doprowadzać do ograniczania dostępności danych, powołując się na to, że możliwe byłoby ich wykorzystanie w takich celach, które byłyby niezgodne z ich przeznaczeniem. Wskazuje się też, że nawet dane osobowe, które w innych okolicznościach mogą być uznane za tzw. dane wrażliwe (dotyczące np. przynależności politycznej, przekonań politycznych i religijnych), nie moga podlegać ochronie przewidzianej dla danych sensytywnych, jeśli dotyczą osób pełniących funkcje publiczne i są przechowywane przez odpowiednie instytucje publiczne. Udostępnianie takich danych zwiększa jawność życia publicznego, a to z kolei sprzyja ochronie praw osób trze$\mathrm{cich}^{28}$. Uchwalenie w 2000 r. ustawy o dostępie do informacji publicznej jest niewatpliwie efektem wspomnianych zaleceń.

Dodać należy, że w systemie prawnym Unii Europejskiej możliwie szeroka dostępność do danych i dokumentów przechowywanych w instytucjach publicznych jest traktowana jako jedna $\mathrm{z}$ istotnych gwarancji transparentności funkcjonowania struktur wspólnotowych. Dyrektywa 95/46/WE Parlamentu Europejskiego i Rady z 24 października 1995 r. w sprawie ochrony osób fizycznych w zakresie przetwarzania danych osobowych i swobodnego przepływu tych danych przewiduje uwzględnienie zasady publicznego dostępu do oficjalnych dokumentów w związku z realizacją wprowadzanych przez tę dyrektywę zasad ${ }^{29}$. Kwestia publicznego dostępu do dokumentów gromadzonych w instytucjach wspólnotowych jest m.in. regulowana przez rozporządzenie (WE) nr 1049/2001 Parlamentu Europejskiego i Rady z 30 maja 2001 r. w sprawie publicznego dostępu do dokumentów Parlamentu Europejskiego, Rady i Komisjii ${ }^{30}$. Wskazuje się tam m.in., że zasadniczo wszelkie dokumenty powinny być publicznie dostępne. W wyraźnie określonych wypadkach potrzeba ochrony interesu prywatnego i publicznego może jednak - na zasadzie wyjątku - uzasadniać ograniczenie dostępu.

28 Szczegółowe omówienie ich treści, zob. J. Barta, P. Fajgielski, R. Markiewicz, Ochrona danych osobowych. Komentarz, wyd. III, Kraków 2004, s. 70-99.

29 Por. akapit 72 preambuły.

30 Dz. Urz. WE L 145 z 31.05.2001. 
Konstytucja w treści art. 61 ust. 2 przewiduje dwie formy udostępniania informacji publicznych, a mianowicie: wglądu do dokumentów oraz wstęp na posiedzenia organów kolegialnych. Ten skromny katalog ustawa o dostępie do informacji publicznej rozszerza i - co paradoksalne - nieco zawęża, zmieniając zresztą - co niekoniecznie musi być bez znaczenia - kolejność form udostępniania informacji publicznych. W art. 3 ust. 1 pkt 1 u.d.i.p. ustawodawca wskazuje, że prawo do informacji publicznej obejmuje uprawnienie do uzyskania informacji publicznej, w tym także informacji przetworzonej, w takim zakresie, w jakim jest to szczególnie istotne dla interesu publicznego. Ponadto, prawo to podejmuje wgląd do dokumentów urzędowych (art. 3 ust. 2 pkt 2 u.d.i.p. - Konstytucja w art. 61 mówi tylko o „dokumentach”) oraz dostęp do posiedzeń kolegialnych organów władzy publicznej pochodzących z powszechnych wyborów (art. 3 ust. 1 pkt 3 u.d.i.p.). W literaturze słusznie zwraca się uwagę na możliwość rozróżnienia „uzyskania informacji” i ,dostępu do informacji”. Uzyskanie to „efektywna treść informacyjna docierająca do odbiorcy”31. Dostęp do informacji musi przyjąć postać „czynnego działania, które rozpoczyna wystapienie zainteresowanego do odpowiedniego organu z wnioskiem o udostępnienie informacji”. Ustawodawca przyznaje uprawnionemu możliwość uzyskania informacji przetworzonej - której nie należy mylić z informacją przekształconą. Ta pierwsza zasadza się na konieczności odpowiedniego zestawienia informacji, samodzielnego ich zredagowania związanego z koniecznością przeprowadzenia przez zobowiązany podmiot czynności analitycznej, której końcowym efektem jest dokument pozwalający na dokonanie przez jednostkę samodzielnej interpretacji i oceny ${ }^{32}$. W innym ujęciu informacją przetworzoną jest informacja, dla której wytworzenia konieczne było intelektualne zaangażowanie podmiotu przygotowującego informację, a nie możliwość dokonania przez żądającego samodzielnej interpretacji oraz oceny. Dlatego też za przetworzenie, według tej koncepcji, trzeba uznać wszelkie działania, które nie przybierają postaci wyłącznie technicznego przeniesienia danych ${ }^{33}$. Przekształcenie informacji wiąże się natomiast ze zmianą nośnika, za

31 Zob. A. Taras, Informowanie obywateli przez administracje, Wrocław-Warszawa-Kraków 1992, s. 27; I. Lipowicz, Konstytucyjne prawo do informacji a wolność informacji, w: Wolność informacji i jej granice, red. G. Szpor, Kraków 1997, s. 13.

32 Zob. H. Izdebski, Ustawa z 6 września 2001 o dostępie do informacji, op. cit., s. 33 .

${ }^{33}$ Zob. M. Jabłoński, K. Wygoda, Ustawa o dostępie, s. 32. 
pomocą którego została ona utrwalona. Takie przekształcenie jest obowiązkiem wynikającym $\mathrm{z}$ art. 12 u.d.i.p. podmiotu udostępniającego informację publiczną. Może to przynieść postać skopiowania takiej informacji, jej wydruku, przeniesienia na odpowiedni powszechnie stosowany nośnik informacji. O przekształceniu informacji w formach wskazanych we wniosku o udostępnienie informacji publicznej mowa w art. 15 ust. 1 u.d.i.p., podczas, gdy o przetworzeniu traktuje art. 3 ust. 1 pkt 1 u.d.i.p. W czynności przekształcenia nie może wystąpić element wpływający na treść przekazywanej informacji. Brak będzie także działania intelektualnego nadającego mu nową treść. Przekształcenie odnosi się więc jedynie do formy, a nie do treści informacji. Informacja przekształcona może się okazać bardziej dostępna, podatniejsza na obróbkę.

Warto zauważyć, że Konstytucja w art. 61 ust. 2 posługuje się terminem dokument, przy czym nie wyjaśnia treści tego pojęcia. W prawie karnym, w myśl § 14 art. 115 k.k., dokumentem jest „każdy przedmiot lub inny zapisany nośnik informacji, z którym jest związane określone prawo, albo który ze względu na zawartą w nim treść stanowi dowód prawa, stosunku prawnego lub okoliczności mające znaczenie prawne”. W świetle doktryny prawa karnego, dokumenty mogą mieć charakter urzędowy, gdyby zostały wystawione przez uprawnione do tego władze, stanowiąc dowód tego, co zostało w treści dokumentu urzędowo poświadczone. Mogą też mieć charakter prywatny, stanowiąc dowód tego, że podpisana pod tym dokumentem osoba złożyła oświadczenie o treści wynikającej $\mathrm{z}$ dokumentu ${ }^{34}$. Pojęciem dokumentów urzędowych posługuje się prawo cywilne. W art. $244 \S 1$ k.p.c. stwierdzono, że dokumenty urzędowe sporządzone w przepisanej formie, przez powołane do tego organy państwowe w ich zakresie działania stanowią dowód tego, co zostało w nich urzędowo zaświadczone. Rangę dokumentów urzędowych mają, sporządzone w przepisanej formie, dokumenty stworzone przez organizacje zawodowe, samorządowe, spółdzielcze i inne organizacje społeczne, w zakresie poruczonych im przez ustawę spraw z dziedziny administracji państwowej. Dokument prywatny stanowi dowód tego, że osoba, która go podpisała, złożyła oświadczenie zawarte w dokumencie. W doktrynie podkreśla się, iż dokumentem w szerokim znaczeniu jest każdy przedmiot, w którym zawarta jest jakaś myśl będąca przejawem ludzkiej działalności. W węższym znaczeniu dokument ma formę pisemną, nieza-

34 Por. K. Buchała, A. Zoll, Kodeks karny część ogólna. Komentarz, t. 1, Kraków 1998, s. 639-640. 
leżnie od substratu materialnego, na którym został sporządzony. Ze względu na swoją treść dokumenty dzielą się na: dyspozytywne, konstytutywne, które obejmują bezpośrednio określoną czynność prawną, stanowiąc jej dowód, i deklaratywne (ściśle dowodowe) stanowiące świadectwo określonego faktu, nazywane też dokumentami informującymi, narratywnymi $^{35}$. Zbliżoną do cywilistycznej definicję przynosi kodeks postępowania administracyjnego. Kodeks postępowania administracyjnego, posługuje się pojęciem dokumentu urzędowego, stwierdzając, że dokumenty takie, sporządzone przez powołane do tego organy państwowe w zakresie ich działania bądź organy jednostek organizacyjnych lub podmioty, w zakresie poruczonych im z mocy prawa lub porozumienia - stanowią dowód tego, co zostało w nich urzędowo stwierdzone (art. $76 \S 1$ k.p.a.). Zauważyć należy, że $§ 2$ art. 76 k.p.a. rozciąga pojęcie dokumentów urzędowych na dokumenty sporządzone przez organy innych państwowych jednostek organizacyjnych oraz organizacji społecznych w zakresie spraw poruczonych im, a wymienionych w art. $1 \S 2$ k.p.a. Będą to więc komunalne jednostki organizacyjne, organizacje zawodowe, samorządowe spółdzielcze oraz inne organizacje społeczne. W tej sytuacji dziennikarz, podobnie jak każdy obywatel, będzie miał dostęp do dokumentów wystawianych i sporządzanych przez wszelkie organy władzy publicznej i osoby pełniące funkcje publiczne oraz do dokumentów organów samorządu gospodarczego i zawodowego, a także innych osób oraz jednostek organizacyjnych w zakresie, w jakim wykonują one zadania władzy publicznej i gospodarują mieniem komunalnym lub majątkiem Skarbu Państwa.

W ustawie o dostępie do informacji publicznej posłużono się własną definicją dokumentu urzędowego, stwierdzając, że jest nim „,treść oświadczenia woli lub wiedzy, utrwalona i podpisana w dowolnej formie przez funkcjonariusza publicznego w rozumieniu przepisów kodeksu karnego, w ramach jego kompetencji, skierowana do innego podmiotu lub złożona do akt sprawy" (art. 6 ust. 2). Oczywiście, w tym rozumieniu należy stosować pojęcie dokumentu w odniesieniu do materii regulowanej przez ustawę o dostępie do informacji publicznej, a więc także w kwestiach, które dotyczą prawa prasowego poprzez art. 3a pr.pr.

Rozważając, czy udzielenie informacji prasie o swojej działalności musi sprowadzać się do udostępniania dokumentów, Sąd Najwyższy, jeszcze przed wejściem w życie Konstytucji z 1997 r., w wyroku z 11 stycznia

35 Por. Kodeks postępowania cywilnego z komentarzem, red. J. Jodłowski, K. Piasecki, t. 2, Warszawa 1989, s. 427-428. 
1996 r. skonstatował, iż określone w art. 4 ust. 1 pr.pr. uprawnienie prasy do uzyskania informacji o działalności organu samorządu terytorialnego nie wyłącza wglądu do akt organu zobowiązanego do udzielania informacji, o ile nie sprzeciwiają się temu przepisy prawa, z których wynika niedopuszczalność ich udostępnienia, w szczególności z uwagi na ochronę tajemnicy państwowej i innej tajemnicy chronionej ustawą oraz dóbr osobistych zaliczonych do sfery prywatności nie wiążącej się z działalnością publiczną ${ }^{36}$. Na gruncie obowiązującej Konstytucji dostęp do wspomnianych akt nie ulega wątpliwości, przy czym jest to prawo zarówno dziennikarza, jak i każdego obywatela. Marginalnie jedynie wypada zauważyć, że w treści uzasadnienia pominięto pojęcie tajemnicy służbowej, chyba przez przeoczenie, bowiem nie sposób przyjąć, aby tajemnicę służbową sąd zaliczył do innej tajemnicy, chronionej ustawa, gdy ta ostatnia - jak wskazano wyżej - obejmuje, w świetle ugruntowanych poglądów doktryny, tzw. tajemnice zawodowe. Zgodzić się należy z tezą Sądu Najwyższego, iż udostępnieniu akt (dokumentów) może sprzeciwiać się wzgląd na potrzebę ochrony dóbr osobistych, zaliczanych do sfery prywatności, a nie wiążących się z działalnością publiczną. Przekonywujący jest też pogląd NSA wyrażony na gruncie nie obowiązującego już w pełni stanu prawnego - jeszcze przed wejściem w życie ustawy o dostępie do informacji publicznej-że „,wolność prasy i innych środków społecznego przekazu, prawo obywateli do uzyskiwania informacji o działalności organów władzy publicznej wraz z dostępem do dokumentów i gwarancje zawarte w art. 10 ust. 2 ratyfikowanej przez Polskę Konwencji o Ochronie Praw Człowieka i Podstawowych Wolności łącznie wymagają kwalifikowania do szczególnie wyjątkowych przypadków odmowy udzielenia środkami społecznego przekazu takich informacji i wglądu do łączących się z nimi dokumentów. Odnosi się to zwłaszcza do działalności organów samorządu terytorialnego, reprezentujących interesy mieszkańców (tworzących wspólnotę samorządowa) przy ustawowej jawności gospodarki finansowej"37.

W literaturze kwestią sporna jest to, czy prawo dostępu do dokumentów dotyczy także tzw. dokumentów wewnętrznych oraz problem czy pojęciem dokumentów, które z mocy art. 3 ust. 1 pkt 2 mogą być przedłożone do wglądu objęte są także dokumenty wewnętrzne powstałe w fazie przygotowywania decyzji. Inne wątpliwości dotyczą problemu, czy

36 Por. wyrok Sądu Najwyższego z 11 stycznia 1996 r., III ARN 57/95, OSNAPiU 1996, nr 13, poz. 179.

37 Zob. wyrok NSA z 19 kwietnia 1999 r., II SA 304/99, LEX nr 46222. 
informację publiczną mogą stanowić nie tylko treści, ale elementy formy dokumentu urzędowego. Warto zauważyć, że po wielu sporach i wątpliwościach uznano, iż o utajnieniu dokumentu i każdej innej informacji decyduje jego treść, a nie charakter posiedzenia, miejsce przechowywania, ani to, kto został $\mathrm{z}$ nim zapoznany.

Ustawodawca, nakładając w art. 4 ust. 2 u.d.i.p. obowiązek udostępniania informacji publicznej na partie polityczne, związki zawodowe i ich organizacje, nie przyznał jednak prawa dostępu do posiedzeń kolegialnych organów tych podmiotów. Tym samym możliwe jest odmówienie wstępu dziennikarzom na salę obrad konwentu bądź zjazdu jakiejś partii - i to niezależnie od tego czy będzie to zgromadzenie ogólnokrajowe, czy też lokalne. Brak także podstaw do przyjęcia, iż dziennikarze mogą uczestniczyć w obradach klubów poselskich. Oczywiście nie ma przeszkód, aby na tego typu zgromadzenie zostali zaproszeni. Jednak ustawa nie daje możliwości wystąpienia z roszczeniem o dopuszczenie do udziału w takowym spotkaniu. Prawo do udziału w posiedzeniu organu kolegialnego nie uprawnia nikogo spoza członków tego organu do zabierania głosu. Tego typu zebranie nie może przekształcić się w wiec bądź w mityng. Także obecni wśród obradujących dziennikarze mogą tylko przysłuchiwać się obradom, natomiast wykluczone jest zabieranie przez nich głosu, zgłaszanie postulatów, wniosków itd. Zgłaszane częstokroć w relacjach prasowych żale i pretensje, że prowadzący obrady np. rady gminy nie dopuścił do głosu obecnych dziennikarzy bądź mieszkańców są jedynie świadectwem braku znajomości przepisów prawa.

Informacje o obowiązującym prawie są również informacjami publicznymi, gdyż stanowią informację o działalności organów władzy publicznej. Odpowiadają więc zakresowi przedmiotowemu tych informacji wskazanemu w art. 61 Konstytucji, a używając terminologii z art. 1 ust. 1 ustawy z dnia 6 września 2001 r. o dostępie do informacji publicznej ${ }^{38}$ są informacjami o sprawach publicznych. Nie stanowi natomiast tego typu informacji polemika z zapadłym rozstrzygnięciem czy żądanie dokonania przez organ wykładni prawa. Tryb udostępniania informacji o obowiązującym prawie został uregulowany w ustawie z dnia 20 lipca $2000 \mathrm{r}$. o ogłaszaniu aktów normatywnych i niektórych innych aktów prawnych ${ }^{39}$, która przewiduje obowiązek ogłoszenia i udostępniania aktów,

38 Dz. U. Nr 112, poz. 1198 z późn. zm.

39 Dz. U. 2005, Nr 190, poz. 1606 z późn. zm. 
jednakże nie wskazuje na obowiązek stosowania k.p.a. Informację udzieloną w trybie ustawy o dostępie stanowić moga jedynie wiadomości o projektowanych aktach prawnych czy aktach nieogłoszonych. Strona ma prawo kwestionowania bezczynności organu w przypadku, gdy uznaje, iż żądane informacje są informacjami publicznymi i powinny być udzielone w trybie wnioskowym na podstawie ustawy o dostępie do informacji publicznej. W przypadku takiej skargi sąd dokonuje kwalifikacji żądanych informacji i w zależności od ich charakteru podejmuje stosowne rozstrzygnięcie.

Podejmując trud ustalenia zakresu pojęcia sprawy publiczne judykatura stwierdziła, iż sprawami publicznymi nie są konkretne indywidualne sprawy danej osoby lub podmiotu niebędącego władzą publiczną lub innym podmiotem wykonującym zadania publiczne. W orzecznictwie wskazano także, że przedmiotowy zakres dostępu do informacji publicznej odnosi się przede wszystkim do informacji „o sprawach publicznych”, zatem poza zakresem tej regulacji prawnej są informacje innego rodzaju, w szczególności o charakterze prywatnym, cywilnym. Pojęcie informacji publicznej ma szeroki zakres i odnosi się do wszelkich spraw publicznych także wtedy, gdy informacja nie została wytworzona przez podmioty publiczne, a jedynie odnosi się do nich. W tej sytuacji wszelkie informacje dotyczące np. majątku publicznego mają charakter informacji publicznej. Żądanie interpretacji znanego stronie dokumentu (opinii biegłego) nie stanowi żądania udostępnienia informacji publicznej. Sprawa nie ma charakteru informacji publicznej, gdy nie dotyczy faktów, lecz stosowania prawa $\mathrm{w}$ indywidualnej sprawie $\mathrm{z}$ zakresu administracji publicznej $\mathrm{w}$ ramach zindywidualizowanego i skonkretyzowanego postępowania administracyjnego. Nie może być więc załatwiona przez udostępnienie informacji w formie czynności materialno-technicznej.

Niezmiernie istotne z punktu widzenia praw i obowiązków dziennikarzy wydaje się stanowisko wyrażone w wyroku WSA we Wrocławiu, który stwierdził, że ustanowione $\mathrm{w}$ art. 2 prawo dostępu do informacji publicznej nie obejmuje w swej treści podmiotowego prawa dostępu do środków przekazu - tak dla dziennikarzy, jak i dla członków określonych gremiów, w celu poinformowania członków określonej społeczności o jakichś zdarzeniach ${ }^{40}$.

40 Wyrok WSA we Wrocławiu z 17 grudnia 2004 r., IV SA/Wr 721/04, cyt. za I. Kamińska, M. Rozbicka-Ostrowska, Dostęp do informacji publicznej, s. 39-40. 
Wnioskodawca nie musi wykazywać powodów, dla których spełnienie jego żądania będzie szczególnie istotne dla interesu publicznego. Jest wręcz odwrotnie. To podmioty zobowiązane do udostępnienia informacji publicznej muszą wykazać brak istnienia przesłanki ustawowej, jeśli zdecydują się wydać w takiej sprawie decyzję odmowną. Wnioskodawca występujący o udostępnienie informacji publicznej nie musi wiedzieć, że żądana przez niego informacja ma charakter informacji publicznej przetworzonej i w związku z tym, nie musi wskazywać powodów, dla których spełnienie jego żądania będzie szczególnie istotne dla interesu publicznego. To podmioty zobowiązane do udostępnienia informacji publicznej muszą wykazać, że objęte wnioskiem żądanie dotyczy informacji publicznej o charakterze przetworzonym. Mogą one odmówić mu udostępnienia żądanej informacji tylko wtedy, gdy wnioskodawca nie wykaże istnienia interesu prawnego. Na tle niezwykle ciekawego stanu faktycznego wynikającego z żądania udostępnienia informacji, które powodowałyby konieczność przetworzenia danych, sporządzenia zestawień i opracowań potrzebnych żądającemu informacji do badań naukowych związanych z pracą doktorską, sąd stanął na stanowisku, że nie ma szczególnie istotnego interesu publicznego w żądaniu takich danych, gdyż praca naukowa jest powszechnie uznawana do interesu prywatnego, który jest przeciwstawny interesowi publicznemu. Podkreślono przy tej okazji, że nawet jeśli praca tworzona jest w interesie publicznym, nie sposób uznać, że jest to szczególnie istotne dla interesu publicznego w rozumieniu art. 3 ust. 1 pkt 1 in fine. Wspomniane pojęcie, jak zauważono w uzasadnieniu, oznacza interes „niezwykły”, „odznaczający się czymś osobliwym”, „mający nadzwyczajne znaczenie",41.

Na tle art. 6 u.d.i.p. WSA w Opolu sformułował niezwykle interesującą tezę, że wnioskiem w świetle ustawy o dostępie do informacji publicznej może być objęte jedynie pytanie o określone fakty, o stan określonych zjawisk. Dodał, że wniosek taki nie może być więc postulatem wszczęcia postępowania w jakiejś sprawie (cywilnej bądź karnej), nie może dotyczyć przyszłych działań organu w sprawach indywidualnych, nie może być polemiką z dokonanymi ustaleniami. Podkreślono jednocześnie, że informacje publiczne odnoszą się do pewnych danych, a nie mogą być środkiem ich kwestionowania ${ }^{42}$. Udostępnienie informacji publicznej

41 Wyrok WSA w Gliwicach z 22 stycznia 2004 r., 4IISA/Ka 2633/03.

42 Wyrok WSA w Opolu z 13 stycznia 2005 r., II SAB/Op 14/04. 
w Biuletynie Informacji Publicznej wyłącza obowiązek ponownego ich udostępnienia ${ }^{43}$. Celnie także przesądziła judykatura, że w celu realizacji prawa do informacji publicznej przez dostęp do posiedzeń kolegialnych organów władzy publicznej pochodzących z wyborów powszechnych nie jest konieczny odrębny wniosek, lecz prawo to realizuje się przez czynność faktyczną, tj. wstęp na posiedzenie ${ }^{44}$.

W sytuacji, gdy wnioskodawca żąda informacji, które nie są informacjami publicznymi lub takich informacji publicznych, do których tryb dostępu odbywa się na odrębnych zasadach, organ nie ma obowiązku wydawania decyzji o odmowie udzielenia informacji. Zawiadamia on jedynie wnoszącego, iż żądane dane nie mieszczą się w pojęciu objętym ustawą o dostępie do informacji publicznej. Odmowa udostępnienia informacji publicznej wymaga wydania decyzji administracyjnej tylko wtedy, gdy chodzi o informację publiczną. Udostępnienie informacji publicznej nie wymaga wydawania decyzji administracyjnej, gdyż w myśl art. 14 ust. 1 u.d.i.p. następuje w sposób i w formie zgodnych z wnioskiem - chyba, że nie pozwalają na to środki techniczne, którymi dysponuje podmiot zobowiązany do udostępnienia.

Do podmiotów zobowiązanych do udzielania informacji w trybie ustawy o dostępie do informacji publicznych zaliczono $\mathrm{w}$ orzeczeniach sądów administracyjnych m.in. uniwersytety, szkoły wyższe, spółdzielnie mieszkaniowe, prezydentów miast, wójtów, Polski Związek Działkowców, rozmaite stowarzyszenia, kuratorów oświaty, organy architektoniczno-budowlane ${ }^{45}$.

Warto pamiętać, że obowiązek udostępniania informacji publicznej - także prasie - ciąży z mocy ustawy o dostępie do informacji publicznej także na związkach zawodowych, ich organizacjach oraz partiach politycznych ${ }^{46}$. Podmioty te nie należąc do sektora finansów publicznych, niedziałające w celu osiagnięcia zysku, nie będące przecież także przedsiębiorcami, zobowiązane są do udzielania prasie informacji o swojej działalności. Obowiązek ten spoczywa także na kościołach i związkach wyznaniowych oraz stowarzyszeniach. Zakres tego obowiązku jest jed-

43 Wyrok WSA w Gdańsku z 1 grudnia 2005 r., II SA/Gd 436/05, ONSAiWSA 2006, nr 6(15), poz. 161.

${ }^{44}$ Wyrok WSA w Bydgoszczy z 18 kwietnia 2006 r., II SA/Bd 11/54/05.

45 Przegląd orzeczeń sądów administracyjnych w tym przedmiocie przynosi cenny zbiór: I. Kamińska, M. Rozbicka-Ostrowska, Dostęp do informacji publicznej, s. 52-82.

46 Art. 4 ust. 2 u.d.i.p. 
nak dość różny. Kościół katolicki udzielając tzw. ślubów konkordatowych, prowadząc lekcje religii w szkołach, prowadząc szkoły i przedszkola, sprawując opiekę duszpasterską w wojsku w czynnej służbie, emitując programy radiowe i telewizyjne - wykonuje zadania publiczne w rozumieniu art. 4 ust. 1 pkt 5 u.d.i.p. Do zadań takich - z pewnymi oporami - wypada zaliczyć także prowadzenie wyższych uczelni i seminariów duchownych. Zakres tych zadań wynika m.in. z treści art. 10, 12, 15, 16 i 20 Konkordatu między Stolicą Apostolską i Rzeczapospolitą Polską ${ }^{47}$. W tym zakresie, na Kościele katolickim spoczywa więc z mocy art. 4 ust. 1 pkt 5 pr.pr. obowiązek udostępniania informacji publicznej - oczywiście w wytyczonym wyżej zakresie, a więc np. o ilości udzielanych ślubów, przygotowaniu katechetów, ich liczbie itd. Przestrzec należy przed próbami rozszerzającego traktowania wspomnianych przepisów, gdyż informacja publiczna dotyczy jedynie zadań publicznych i nie może dotykać sfery kultu. Ponadto pamiętać należy o treści art. 15a dotyczącego zawierania związków małżeńskich oraz w zakresie spraw majątkowych - o art. 55 ustawy o stosunku Państwa do Kościoła katolickiego w Rzeczypospolitej Polskiej z dnia 17 maja 1989 r. ${ }^{48}$ Zauważyć należy, że kościelne osoby prawne są zwolnione od opodatkowania $\mathrm{z}$ tytułu przychodów ze swojej działalności niegospodarczej. W tym zakresie osoby te nie mają obowiązku prowadzenia dokumentacji wymaganej przez przepisy o zobowiązaniach podatkowych. Dochody z działalności gospodarczej kościelnych osób prawnych oraz spółek, których udziałowcami są wyłącznie te osoby, są zwolnione od opodatkowania w części, w jakiej zostały przeznaczone w roku podatkowym lub w roku po nim następującym na cele kultowe, oświatowo-wychowawcze, naukowe, kulturalne, działalność charytatywno-opiekuńczą, punkty katechetyczne, konserwację zabytków oraz na inwestycje sakralne i te inwestycje kościelne, których przedmiotem są punkty katechetyczne i zakłady charytatywno-opiekuńcze, jak również remonty tych obiektów. Kościelne osoby prawne są zwolnione od opodatkowania i od świadczeń na fundusz gminny i fundusz miejski, od nieruchomości lub ich części, stanowiących własność tych osób lub używanych przez nie na podstawie innego tytułu prawnego na cele niemieszkalne, z wyjątkiem części zajmowanej na wykonywanie działalności gospodarczej ${ }^{49}$.

47 Dz. U. 1998, Nr 51, poz. 318.

48 Dz. U. 1989, Nr 29, poz. 154.

49 Art. 55 ustawy o stosunku Państwa do Kościoła katolickiego w Rzeczypospolitej Polskiej. 
Niemniej, Kościół katolicki nie będąc przedsiębiorcą, ani podmiotem zaliczanym do sektora finansów publicznych i nie działając przecież oczywiście w celu osiagnięcia zysku jest $\mathrm{z}$ mocy art. 4 ust. 1 zobowiązany $\mathrm{z}$ racji treści tego przepisu, do udzielania prasie informacji o swojej działalności. Zważywszy na delikatność materii, której dotyczy sfera działalności Kościoła, można mieć wątpliwości, czy obowiązek ten nie sięga zbyt daleko. Treść ustawy nie pozostawia jednak wątpliwości do jego zakresu. W literaturze zauważa się, że kościelne osoby prawne, prowadząc działalność gospodarczą w dziedzinach tradycyjnie związanych z działalnością kościelną (prowadzenie placówek wychowawczych, placówek leczniczych lub sanatoryjnych, działalność wydawnicza kulturalna, obrót artykułami kultowymi, najem pomieszczeń) „mają status przedsiębiorcy w rozumieniu art. 4 u.s.d.g." ${ }^{, 50}$. Gdyby podzielić tę argumentację, wówczas takie kościelne osoby prawne jako przedsiębiorcy zobowiązane były by z mocy art. 4 ust. 1 pr.pr. do udzielania prasie informacji o swojej działalności. Warto dodać, że wspomniane osoby prawne Kościoła katolickiego nie podlegają wpisowi do rejestru przedsiębiorców - z wyjątkiem prowadzących działalność gospodarczą fundacji i stowarzyszeń, a także spółek, których udziałowcami są wyłącznie osoby prawne Kościoła katolickiego.

Identyczne obowiązki w zakresie udostępniania informacji publicznej ciążą na tych kościołach i związkach wyznaniowych, których sytuację prawną regulują ustawy. W treści ich określono zasady prowadzenia nauki religii, tworzenia szkół, także wyższych, działalności wydawniczej, utrzymywania cmentarzy. Prawa do zawierania przed duchownymi małżeństw wywołujących skutki cywilne w grupie kościołów i związków wyznaniowych, których status reguluje ustawa, nie przyznano: Muzułmańskiemu Związkowi Wyznaniowemu, Karaimskiemu Związkowi Wyznaniowemu, Wschodniemu Kościołowi Staroobrzędowemu oraz Kościołowi Katolickiemu Mariawitów.

Obowiązek udostępniania informacji publicznej ciążący na innych kościołach i związkach wyznaniowych, których status nie jest uregulowany przez ustawę, oraz tych, których duchownym nie przyznano uprawnień do udzielania związków małżeńskich wywierających takie skutki, jak małżeństwa zawierane przed urzędnikiem stanu cywilnego, jest chociażby $z$ tej

50 Zob. R. Skubisz, M. Trzebiatowski, Kościelne osoby prawne jako przedsiębiorcy rejestrowi (na przykładzie osób prawnych Kościoła katolickiego), „Przegląd Prawa Handlowego" 2002, nr 3, s. 8 i n. 
tylko przyczyny węższy. Pamiętać należy, że mimo formalnego równouprawnienia wyznań, regulacje odnoszące się także do działalności gospodarczej innych kościołów i związków wyznaniowych nie są tak daleko idące, jak te, którymi cieszy się Kościół katolicki. Wbrew poglądom doktryny, za niedopuszczalne należy uznać stosowanie per analogiam art. 55 ustawy o stosunku Państwa do Kościoła katolickiego w Rzeczypospolitej Polskiej w odniesieniu do pozostałych kościołów i związków wyznanio$\mathrm{wych}^{51}$. W polskim systemie prawnym stosunki między państwem a kościołami i związkami wyznaniowymi reguluje ustawa z dnia 17 maja $1989 \mathrm{r}$. o gwarancjach wolności sumienia i wyznania ${ }^{52}$. Kościoły i związki wyznaniowe mogą tworzyć organizacje mające na celu działalność na rzecz formacji religijnej, kultu publicznego oraz przeciwdziałania patologiom społecznym. W stosunku do tych organizacji nie stosuje się prawa o stowarzyszeniach, jeśli nie mają osobowości prawnej. Niektóre z nich moga być tworzone tylko po uzyskaniu aprobaty, niektóre na podstawie uchwały właściwych władz religijnych. Stanowczo podkreślić należy, że obowiązek udzielania informacji publicznej ciąży na kościołach i związkach wyznaniowych tylko w tym zakresie, $w$ jakim wykonują one zadania publiczne lub dysponują majątkiem publicznym ${ }^{53}$, a więc obowiązek ten nie dotyczy sfery kultu.

Stosunek przepisów prawa prasowego do treści ustawy o dostępie do informacji publicznej, a w konsekwencji także do art. 61 Konstytucji, powodować może - mimo treści art. 3a pr.pr. - wątpliwości. Zwrócił na nie uwagę NSA stwierdzając w uzasadnieniu wyroku z 28 listopada 2003 r., że w świetle art. 4 ust. 1 ustawy - Prawo prasowe i art. 61 Konstytucji w pojęciu udostępnienia informacji mieści się nie tylko dostarczenie jej prasie, ale również udostępnienie źródeł tych informacji. Obejmuje więc ono udostępnianie prasie dokumentów, akt, materiałów, które świadczą lub mogą świadczyć o działalności organów administracji publicznej. Prasa ma przy tym zarówno prawo do informacji przetworzonej, jak i wglądu do dokumentów i materiałów będących w posiadaniu organu. Jak podkreślił NSA, zakres przedmiotowy żądanych informacji wynika z art. 61 Konstytucji RP. Obejmuje on prawo do uzyskiwania informacji o działalności organów władzy publicznej oraz osób pełniących funkcje publiczne,

51 Zob. W. J. Katner, Prawo działalności gospodarczej. Komentarz. Orzecznictwo. Piśmiennictwo, Warszawa 2003, s. 37.

52 T.j. Dz. U. 2005, Nr 231, poz. 1965.

53 Art. 4 ust. 1 pkt 5 u.d.i.p. 
w tym także dostęp na podstawie art. 61 ust. 2 do dokumentów urzędowych. Charakter takich dokumentów mają akta spraw administracyjnych, a w szczególności wydane w sprawie decyzje administracyjne ${ }^{54}$. Zgadzając się generalnie $\mathrm{z}$ treścią wspomnianego orzeczenia wypada zauważyć, że dostęp do dokumentów oczywiście wynika także, a może przede wszystkim z treści art. 3 ust. 1 pkt 2 u.d.i.p.

$\mathrm{Na}$ aprobatę zasługuje także wyrażone w judykaturze stanowisko, że błędnym jest twierdzenie, iż imię i nazwisko oraz stanowiska pracownika państwowego (z wyjątkiem służb specjalnych) lub samorządowego podlega ochronie danych osobowych na podstawie przepisów ustawy z dnia 29 sierpnia 1997 r. o ochronie danych osobowych ${ }^{55}$. Tego typu dane nie podlegają żadnej ochronie, natomiast w określonych sytuacjach nie powinien być dostępny prywatny adres i telefon takiego pracownika. $Z$ art. 61 ust. 2 Konstytucji RP wynika obowiązek udostępniania danych już istniejących (dokumenty). Żaden przepis nie zobowiązuje organów państwowych i samorządowych do wykonywania, wyłącznie na potrzeby prasy, specjalnych wykazów, zestawień czy innego rodzaju opracowywanych danych ${ }^{56}$.

W orzecznictwie dość mocno ugruntowana jest teza, że w świetle art. 61 Konstytucji RP prawo do informacji jest publicznym prawem obywatela, które odbywa się na zasadach skonkretyzowanych w ustawie o dostępie do informacji publicznej. Prawo do informacji jest zatem zasadą, a wyjątki od niego powinny być interpretowane ściśle. Akceptując ten pogląd oraz towarzyszące mu stwierdzenie, że art. 156 k.p.k. nie może być traktowany rozszerzająco nie sposób zgodzić się z dalszymi wywodami zawartymi w wyroku NSA z 28 listopada 2003 r. $^{57}$, który suponuje, że art. $156 \S 5$ k.p.k. wyraźnie wskazuje, że odmienny tryb dostępu dotyczy jedynie spraw w toku postępowania przygotowawczego i nie odnosi się on do spraw zakończonych umorzeniem, a w szczególności z konstatacją, że w odniesieniu do takich spraw znajduje zastosowanie ustawa o dostępie do informacji publicznej. Wbrew poglądom wyrażonym w uzasadnieniu wspomnianego wyroku, udostępnienie akt sądowych w sprawie karnej, nawet prawomocnie zakończonej nie odbywa się według zasad przewi-

54 Zob. wyrok NSA z 28 listopada 2003 r., II SA 3412/03, LEX nr 167180.

55 Dz. U. Nr 133, poz. 883.

56 Zob. wyrok NSA w Warszawie z 24 czerwca 1999 r., II SA 686/99, LEX nr 46190.

57 Wyrok NSA z 7 marca 2003 r., II SA 3572/02, ,,Wokanda” 2003 nr 10, s. 35. 
dzianych w ustawie o dostępie do informacji publicznej, a wedle przepisów k.p.k., które jednoznacznie i ściśle regulują zasady udostępniania akt. Warto zauważyć, że treść art. 156 k.p.k. została głęboko zmodyfikowana nowelą wchodzącą w życie 1 lipca 2003 r. - a więc już po wejściu w życie ustawy o dostępie do informacji publicznej. Gdyby ustawodawca istotnie uważał, że zasady dostępu do akt reguluje wspomniana ustawa, dokonałby innych modyfikacji istniejącego przepisu art. 156 k.p.k. Podkreślić należy, że wspomniane orzeczenie nie zostało zauważone na gruncie prawa karnego i nie odnotowali go komentatorzy. Jest rzeczą niezaprzeczalną, że wspomniany pogląd NSA wydaje się całkowicie błędny i wynikający z nieuwzględnienia zasady lex specialis derogat legi generali. Nie oznacza to oczywiście, iż domagający się udostępnienia takowych akt nie uzyska do nich dostępu, a jedynie to, że podstawa udostępnienia będzie inna. Oczywiście niejako osobny problem stanowić będzie kwestia objęcia tajemnicą całości lub części takich materiałów. Podobnie mylne jest stanowisko zawarte w wyroku WSA w Warszawie, w którym stwierdzono, że treść wyroku sądowego nie tylko stanowi zgodnie z art. 1 ust. 1 u.d.i.p. informację o sprawach publicznych, ale stosownie do art. 6 ust. 1 pkt 4 lit. a) jest rodzajem informacji dotyczącej treści i postaci dokumentów urzędowych, a więc $z$ tego tytułu podlega udostępnieniu w trybie i na zasadach przewidzianych ustawą o dostępie do informacji publicznej ${ }^{58}$. Nie negując faktu, że wyrok sądowy jest dokumentem urzędowym wypada zauważyć, że treść wyroku jest ogłaszana publicznie, a o udostępnieniu wyroku decyduje nie ustawa o dostępie do informacji publicznej, lecz odpowiednie przepisy właściwego kodeksu postępowania. Wyrok, jako dokument urzędowy, może zawierać informacje dotyczące danych osobowych, np. pokrzywdzonej w sprawie o gwałt lub inne tzw. „wrażliwe” informacje i nie może być udostępniany w trybie i na zasadzie ustawy o dostępie do informacji publicznej, lecz - z przyczyn wskazanych wyżej - w oparciu o właściwe przepisy kodeksu postępowania. Warto przypomnieć, że w sprawach karnych podanie wyroku do publicznej wiadomości jest środkiem karnym. Będąc dodatkową niejako „dolegliwością” dla skazanego, stanowi narzędzie racjonalnej polityki karnej.

Warto zauważyć, że ustawodawca zmienił w stosunku do stanu prawnego sprzed wejścia w życie kodeksu karnego z 1997 r. przesłanki orzeka-

58 Wyrok WSA w Warszawie z 11 lutego 2004 r., II SAB 408/03, omówienie „Rzeczpospolita” 2004, nr 36, s. C1. 
nia o podaniu wyroku do publicznej wiadomości ograniczając możliwość zastosowania takiego środka jedynie do wypadków wyraźnie w ustawie określonych i może to nastąpić w sposób wskazany przez sąd orzekający. Okoliczności tej zdaje się w ogóle nie zauważać w swoim orzeczeniu Naczelny Sąd Administracyjny. Gdyby istotnie zastosować dyspozycję art. 6 ust. 1 pkt 4 lit. a) u.d.i.p., to wówczas wyrok mógłby trafić do każdego z chętnych do posiadania takiego dokumentu. Każdy też mógłby publikować taki wyrok, np. poprzez zamieszczenie jego tekstu w oryginalnej postaci w Internecie. W tym momencie nie sąd, a obywatele decydowaliby o środku karnym. Z podobnych przyczyn niedopuszczalnym jest udostępnianie w trybie art. 6 ust. 1 pkt 4 lit. a) u.d.i.p. (a nie w trybie wskazanym przez właściwy kodeks) wyroków w sprawach o ustalenie ojcostwa czy o rozwód. Dążenie do transparentności, które legło u podstaw wyroku WSA w Warszawie 11 lutego 2004 r. nie może przeważać nad interesami osób zainteresowanych, których nie wolno wydawać na żer ciekawych sąsiadów, wścibskich znajomych i żądnych sensacji dziennikarzy. Reguły kodeksów postępowań są dostatecznie jasne, sprawdzone, precyzyjne i według nich tylko można decydować o zasadach dostępu do orzeczeń sądowych.

Za celne i dobrze uzasadnione wypada uznać stanowisko sprowadzające się do twierdzenia, że odmowa wydania żądanych kopii dokumentów $z$ akt sprawy postępowania karnego nie może być kwestionowana poprzez ustawę o dostępie do informacji publicznej, lecz w drodze zażalenia składanego w trybie art. 159 k.p.k. ${ }^{59}$

Nie tylko dziennikarz, ale każdy obywatel, w świetle art. 61 ust. 1 i 2 Konstytucji, ma prawo do uzyskiwania informacji o działalności organu władzy publicznej oraz osób pełniących funkcje publiczne. Prawo to obejmuje również uzyskiwanie informacji o działalności organów samorządu gospodarczego i zawodowego, a także innych osób oraz jednostek organizacyjnych w zakresie, w jakim wykonują one zadania władzy publicznej i gospodarują mieniem komunalnym lub majątkiem Skarbu Państwa. Pod pojęciem władzy publicznej należy rozumieć władzę ustawodawczą, wykonawczą oraz sądowniczą, a także organy władzy kontrolnej, o których Konstytucja wprost w art. 10 ust. 2 nie stanowi. W obrębie władzy wykonawczej dyspozycja art. 61 ust. 1 Konstytucji obejmuje administracje rządową i samorządową, a także organy władzy publicznej nie pod-

59 Postanowienia NSA we Wrocławiu z 7 stycznia 2003 r., II SAB/Wr 199/02. 
porządkowane rządowi i nie mające charakteru organów samorządowych. Konstytucja rozszerza prawo do informacji, które do chwili jej wejścia w życie służyło obywatelowi jedynie jako stronie bądź uczestnikowi postępowania. Wcześniejsze rozszerzenia uprawnień administracyjnych miały charakter podmiotowy i dotyczyły: posłów, senatorów, radnych, członków organizacji społecznych. Rozszerzenia przedmiotowe obejmowały łatwiejszy dostęp do wyodrębnionych zbiorów danych, np.: rejestry prawa handlowego, partii politycznych, związków zawodowych ${ }^{60}$. Prawo do uzyskiwania informacji obejmuje po pierwsze - dostęp do dokumentów, po drugie - wstęp na posiedzenia pochodzących z wyborów powszechnych kolegialnych organów władzy publicznej, z możliwością rejestracji dźwięku i obrazu. Dostęp do dokumentów nie oznacza jednak prawa otrzymywania bezpłatnego odpisu bądź fotokopii, a zasadza się jedynie na możliwości zapoznania się $\mathrm{z}$ treścią dokumentów ${ }^{61}$.

Ograniczenie prawa do informacji może nastąpić wyłącznie ze względu na określoną w ustawach potrzebę ochrony wolności i praw innych osób oraz porządku publicznego, bezpieczeństwa lub ważnego interesu gospodarczego ${ }^{62}$. Tryb udzielania informacji przez Sejm i Senat określają ich regulaminy, w odniesieniu do pozostałych organów czynią to szczegółowe ustawy. Możliwość ograniczenia prawa do informacji pozwala w określonych sytuacjach na uchylenie jawności obrad Sejmu lub Senatu w sytuacji, gdy przedmiotem ich będzie problematyka bezpieczeństwa państwa, udział w sojuszach obronnych, problematyka porządku publicznego. W myśl art. 172 ust. 2 i 3 uchwały Sejmu Rzeczypospolitej Polskiej z 30 lipca 1992 r. regulamin Sejmu Rzeczypospolitej Polskiej ${ }^{63}$ Sejm rozstrzyga o tajności obrad bez udziału publiczności i przedstawicieli prasy, radia i telewizji, po wysłuchaniu uzasadnienia wniosku bez debaty. Uchwała o tajności obrad podejmowana jest bezwzględną większością głosów w obecności co najmniej połowy ogólnej liczby posłów. Generalnie posiedzenia Sejmu sąjawne, a jawność tę zapewnia się poprzez umożliwienie prasie, radiu i telewizji sporządzenia sprawozdań z posiedzeń Sejmu ${ }^{64}$.

60 Por. I. Lipowicz, Zagadnienia prawne obiegu informacji w administracji, w: Informacja i informatyka $w$ administracji publicznej, red. G. Szpor; W. Taras, Informacja $w$ postępowaniu administracyjnym, ibidem.

${ }^{61}$ Por. Konstytucje Rzeczypospolitej, red. J. Boć, s. 114-115.

62 W przedmiocie powyższych ograniczeń por. wyżej uwagi do art. 1 pr.pr.

63 T.j. MP 2002, Nr 23, poz. 398 z późn. zm.

64 Art. 172 ust. 1 pkt 2 regulaminu Sejmu. 
W myśl art. 154 ust. 5 regulaminu Sejmu na posiedzeniach komisji Sejmu, za zgodą jej przewodniczącego, mogą być obecni dziennikarze prasy, radia i telewizji. W myśl art. 36 ust. 2 i 3 uchwały Senatu z 23 listopada 1990 r. regulamin Senatu ${ }^{65}$ Senat, na wniosek marszałka lub co najmniej dziesięciu senatorów, może uchwalić tajność obrad, jeżeli wymaga tego dobro państwa. Uchwalę w tej sprawie podejmuje bezwzględną większością głosów, w obecności co najmniej połowy ustawowej liczby senatorów, na posiedzeniu niejawnym. Generalnie posiedzenia Senatu są jawne, a wyrazem tej jawności jest umożliwienie prasie, radiu i telewizji publikowania sprawozdań z posiedzeń. W znacznie mniejszym zakresie możliwość utajniania obrad dotyczyć będzie rad gminy, w pierwszym rzędzie wynikać ona może z potrzeby ochrony praw osób fizycznych i podmiotów gospodarczych, rzadziej z uwagi na potrzebę ochrony porządku publicznego. W odniesieniu do organów samorządu terytorialnego - rad gmin, powiatów, sejmików samorządowych istnieje, potwierdzona praktyką niektórych z tych organów, obawa przed bezpodstawnym ograniczaniem praw do informacji przez niezasadne utajnianie obrad po to, aby uniemożliwić wstęp na posiedzenie dziennikarzom. Jako całkowicie niedopuszczalna jawi się praktyka wypraszania dziennikarzy, niektórych tylko gazet, z posiedzeń kolegialnych organów władzy publicznej pochodzących z wyboru, wyłącznie z tej przyczyny, iż, zdaniem członków takich organów, istnieje potencjalna bądź realna obawa, że dziennikarze określonej gazety przedstawią przebieg obrad krytycznie, a nawet, że je celowo zniekształca.

Ustawowym ograniczeniem dostępu dziennikarzy do udziału w obradach organów kolegialnych jest art. 22 ust. 1 ustawy z 8 sierpnia 1996 r. o Radzie Ministrów ${ }^{66}$. W myśl wspomnianego przepisu, posiedzenia Rady Ministrów mają charakter niejawny, jednak Prezes Rady Ministrów, z własnej inicjatywy lub na wniosek członka Rady Ministrów, może zezwolić zaproszonym osobom na przysłuchiwanie się posiedzeniu Rady Ministrów w całości lub w części oraz na udzielanie wyjaśnień. Niemniej Rada Ministrów obowiązana jest informować opinię publiczną o przedmiocie posiedzenia oraz o podjętych rozstrzygnięciach. Nie dotyczy to jednak spraw, w stosunku do których Prezes Rady Ministrów zarządził tajność obrad. Podkreślić należy, iż ustawy nie regulują sprawy wstępu dziennikarzy na posiedzenia takich organów kolegialnych, jak: Krajowa Rada

65 T.j. MP 2002, Nr 54, poz. 741 z późn. zm.

66 T.j. Dz. U. 2003, Nr 24, poz. 199 z późn. zm. 
Radiofonii i Telewizji, Krajowa Rada Sądownictwa, a także udziału w posiedzeniach kolegialnych organów samorządu zawodowego. Niewątpliwie jednak dziennikarze mają prawo uzyskiwania informacji o treści podjętych uchwał i przebiegu obrad.

Ustawodawca w treści art. 3 ust. 1 pkt 3 u.d.i.p. zagwarantowal dostęp do posiedzeń kolegialnych organów władzy publicznej. Takimi kolegialnymi organami są Zgromadzenie Narodowe, Sejm, Senat, rada gminy, rada powiatu, sejmik województwa. Pamiętać należy o podniesionych wątpliwościach co do objęcia Sejmu i Senatu zakresem działania u.d.i.p., natomiast niewątpliwie, wstęp na posiedzenie kolegialnych organów władzy publicznej pochodzących z wyboru, w tym także na posiedzenie Sejmu i Senatu, wynika z treści art. 61 ust. 2 Konstytucji. O związaniu Sejmu i Senatu dyspozycją art. 61 ust. 2 Konstytucji, a nie treścią ustawy o dostępie do informacji publicznej, zdaje się świadczyć pośrednio treść regulaminu tych organów, które wprowadzają daleko idące ograniczenia w postaci przepustek, których tryb i zasady wydawania nie sąjednoznacznie określone. Warto pamiętać, że w ramach tych organów mogą działać różnego typu wewnętrzne pomocnicze organy kolegialne. Posiedzenia tych organów z mocy art. 18 ust. 2 u.d.i.p. sąjawne i dostępne, o ile stanowią tak przepisy ustaw. Wstęp na takie posiedzenia gwarantuje nie tylko przysłuchiwanie się obradom, lecz także możliwość utrwalenia ich przebiegu. NSA w wyroku z 30 października 2002 r. stwierdził, iż komisje sejmowe nie są organami władzy publicznej pochodzącymi z wyborów, lecz stanowią organy pomocnicze Sejmu. Podkreślił przy tym, iż regulamin Sejmu z 1992 r. nie wprowadza jawności prac komisji sejmowych ${ }^{67}$. Nie negując formalnoprawnej strony wspomnianego orzeczenia wypada jedynie zauważyć, że w praktyce, na obrady poszczególnych komisji bywają zapraszani dziennikarze. Może to rodzić obawę o naruszenie zasady równości wobec prawa, gdyby okazało się, że istnieje klucz polityczny takowych zaproszeń. Zauważyć przy tym należy, że gremialny udział dziennikarzy w obradach komisji niekoniecznie musi sprzyjać dobrej jakości prac. Należy też pamiętać o odrębnych regulacjach dotyczących sejmowych komisji śledczych (zob. niżej). Z przywołanym judykatem koresponduje pogląd wyrażony w wyroku WSA w Bydgoszczy, że komisje działające przy radzie gminy nie są organami pochodzącymi z powszechnych wyborów. Stwierdzając to Sąd skonstatował, że obowiązujące przepisy aktualnie nie

67 Wyrok NSA w Warszawie z 30 października 2002 r., II SAB 154/02. 
stanowią o jawności obrad kolegialnych organów pomocniczych. Zatem jedynie sam organ pomocniczy lub statut danej jednostki samorządu terytorialnego może wprowadzić zasadę jawności posiedzeń ${ }^{68}$.

\section{Możliwość utrwalania przebiegu obrad przez rejestrację dźwięku} lub obrazu wynika jedynie $z$ treści art. 61 ust. 2 Konstytucji. Ustawa o dostępie do informacji publicznej o takich możliwościach milczy, co potwierdza tezę o różnym zakresie przedmiotowym obu wspomnianych aktów normatywnych. Nie powtarzając treści art. 61 ust. 2 Konstytucji co do możliwości rejestracji dźwięku lub obrazu z przebiegu obrad, w art. 18 ust. 3 u.d.i.p. stwierdzono, iż „w miarę potrzeby zapewnia się transmisję audiowizualną lub teleinformatyczną z posiedzeń kolegialnych organów władzy publicznej. Jest to istotna różnica, gdyż o potrzebie takiej, w myśl ustawy, nie będzie mógł decydować zainteresowany podmiot, a organ kolegialny, którego posiedzenie ma być zarejestrowane w formie dźwięku lub obrazu. On także będzie decydować o sposobie rejestracji, np. ujęciach, kadrowaniu, montażu itd. Wyraźnie umożliwiałoby to niedopuszczalne w gruncie rzeczy ograniczenie dostępu do informacji publicznej. Wobec faktu, że Konstytucja w art. 61 ust. 2 dopuszcza szerszą możliwość rejestracji, wypada uznać - mając na względzie dyspozycję art. 8 ust. 2 Konstytucji - że rejestracja dźwięku i obrazu z posiedzeń kolegialnych organów władzy publicznej odbywać się może na zasadach przewidzianych właśnie w art. 61 ust. 2 Konstytucji. Dodać należy, że rejestracją jest nie tylko utrwalanie przebiegu obrad na taśmie filmowej, magnetofonowej, w zapisie analogowym bądź cyfrowym - lecz także fotografowanie wszystkich osób obecnych na sali, nawet tych, które nie zabierają głosu, nie są członkami organu kolegialnego, a jedynie przysłuchują się obradom. Możliwość ta wynika z treści art. 81 ust. 2 pkt 2 p.a.p.p. Prawo do rejestracji dźwięku lub obrazu przysługuje przy tym nie tylko dziennikarzom, lecz także każdemu z obecnych. Wypada zauważyć, że jeszcze przed wejściem w życie ustawy o dostępie do informacji publicznej, NSA orzekł, iż uchwała rady gminy zakazująca rejestracji przebiegu jej obrad narusza konstytucyjną zasadę jawności działania organów władzy publicznej ${ }^{69}$.

Sposób utrwalania nie może jednak zakłócać toku obrad, a o utrwalaniu uczestnicy ich winni zostać poinformowani. Uprawnienie do uczestniczenia $\mathrm{w}$ posiedzeniu wspomnianych organów nie pozwala jednak na

68 Wyrok WSA w Bydgoszczy z 4 kwietnia 2006 r., SAB/Bd 1153/05.

${ }^{69}$ Zob. wyrok NSA z 12 października 1999 r., II S.A. 220/99, „Wokanda” 2000, nr 7, poz. 41 . 
domaganie się wpuszczenia na salę obrad, jeśli pojemność sali nie pozwala na uczestnictwo wszystkich zainteresowanych. Za niewłaściwą i godzącą w samą istotę art. 3 ust. 1 pkt 3 u.d.i.p. oraz w treść art. 61 ust. 2 Konstytucji należy uznać praktykę organizowania obrad w salach szczególnie małych i selekcjonowania uczestników np. pod kątem sympatii politycznych. Za szczególnie naganne uznać należy praktyki uniemożliwiania uczestniczenia w obradach dziennikarzom prasy opozycyjnej. Zupełnie niedopuszczalne i naruszające samą istotę wolności wypowiedzi są praktyki cenzurowania utrwalanych treści bądź uzależniania wstępu na salę obrad od przedstawienia po ich zakończeniu materiałów mających być podanych do publicznej wiadomości. Warunkiem dostępu do posiedzeń kolegialnych organów władzy publicznej pochodzących z wyboru jest dysponowanie wiedzą o miejscu i czasie takich posiedzeń. Informacja takowa powinna być znana wszystkim potencjalnie zainteresowanym z odpowiednim wyprzedzeniem. Oczywiście, wyjątkiem muszą być posiedzenia nadzwyczajne, zwoływane w ostatniej chwili.

Poważny problem może nastręczać w praktyce bezpośrednia relacja radiowa bądź telewizyjna z przebiegu Sejmu, Senatu, a także pozostałych kolegialnych organów władz publicznych pochodzących z wyboru. Sam wybór godziny przekazu może z jednej strony narazić na zarzut manipulacji, z drugiej - przyczyniając się do tzw. teatralizacji wystąpień - wypaczać sens i tok obrad. Możliwość manipulowania kamerami, kadrowania prowadzić może do zniekształcenia obiektywnego obrazu przebiegu posiedzenia. Dotyczy to w szczególności posiedzeń, których tematyka wywołuje szczególne zainteresowanie społeczne oraz posiedzeń niektórych organów Sejmu, takich jak komisje śledcze. Wypada zauważyć, że w myśl art. 16a ustawy z dnia 21 stycznia 1999 r. o sejmowej komisji śledczej, komisja może zezwolić przedstawicielom prasy, w rozumieniu przepisów ustawy z dnia 26 stycznia 1984 r. pr.pr. na dokonywanie za pomocą aparatury utrwalenia obrazu lub dźwięku z posiedzenia komisji, gdy przemawia za tym interes publiczny; dokonywanie tych czynności nie będzie utrudniać przebiegu posiedzenia, a ważny interes osoby wezwanej nie sprzeciwia się temu ${ }^{70}$. W doktrynie zwraca się uwagę, że zezwolenie na utrwalanie obrazu lub dźwięku z posiedzenia komisji może być jednorazowe i dotyczyć konkretnego posiedzenia lub ogólne. Warto zauważyć, że przewod-

70 Zob. Dz. U. 1999, Nr 35, poz. 321, zm. 2005, Nr 122, poz. 1023, art. 16a został dodany przez art. 1 pkt 14 ustawy z dnia 3 czerwca 2005 r. (Dz. U. 2005, Nr 122, poz. 1023). 
niczący komisji, który reprezentuje na zewnątrz komisję oraz działa w jej imieniu może podjąć decyzję o zezwoleniu przedstawicielom prasy na dokonywane za pomocą aparatury utrwalania obrazu lub dźwięku z posiedzenia komisji jedynie na podstawie uchwały komisji. Względy porządkowe mogą oczywiście zmuszać do ograniczenia liczby sprawozdawców, ale kwestie te muszą być wyraźnie rozstrzygnięte w uchwale. Nie sposób się zgodzić z taką interpretacją ustawy, że komisja uchwałą przesądza o możliwości utrwalania obrazu lub dźwięku, a przewodniczący w formie decyzji indywidualnej wskazuje podmioty uprawnione do utrwalania ${ }^{71}$. Teoretyczna strona sprawozdań z posiedzeń sejmowej komisji śledczej nie została jak dotąd opracowana, mimo iż posiedzenia ich wywołały liczne komentarze i stały się przedmiotem opracowań publicystycznych, nawet $\mathrm{w}$ formie książkowej ${ }^{72}$.

Konstytucja powierza określenie trybu udzielania informacji ustawom, a w odniesieniu do Sejmu i Senatu - ich regulaminom. Co ciekawe, nie wskazano regulaminu Zgromadzenia Narodowego, jako aktu prawnego określającego tryb udzielania informacji w odniesieniu do tego organu. W formie ustawy może nastąpić jedynie ograniczenie konstytucyjnego prawa do informacji. Ustawa o dostępie do informacji publicznej $\mathrm{w}$ art. 7 wskazuje, że udostępnianie informacji publicznych następuje w drodze: ogłaszania informacji publicznej, w tym dokumentów urzędowych w Biuletynie Informacji Publicznej, w formie wstępu na posiedzenia organów władzy publicznej pochodzących z wyboru. Informacja publiczna, która nie została udostępniona w Biuletynie może być udostępniana na wniosek, a jeżeli może być niezwłocznie udostępniona - to jest udostępniana w formie ustnej lub pisemnej - bez pisemnego wniosku ${ }^{73}$. Informacja taka może być udostępniona bądź w drodze wyłożenia lub wywieszenia w miejscach ogólnie dostępnych, bądź przez zainstalowanie w takich miejscach urządzenia umożliwiającego zapoznanie się z takową informa$\operatorname{cją}^{74}$. Udzielenie informacji następuje więc w formie czynności materialno-technicznej, ze wszystkimi konsekwencjami procesowymi. Informacja

71 Taką dyskusyjną tezę można wyinterpretować z komentarza do ustawy o sejmowej komisji śledczej, zob. M. Lewandowski, A. Kowalski, T. Osiński, Sejmowa komisja śledcza. Ustawa z 1999 r. z komentarze, Warszawa 2006, s. 204-205.

72 Zob. m.in. M. Bil, A. Błoński, A. Małkiewicz, Komisja Rywina. Próba spojrzenia politologicznego, Wrocław 2005, tamże - wybrana literatura.

Art. 10 ust. 1 i 2 u.d.i.p.

74 Art. 11 u.d.i.p. 
niepełna może być przez żądającego informacji uznana za brak informacji. Warto zauważyć, że podmiot udostępniający informację publiczną jest zobowiązany zapewnić możliwość jej kopiowania, albo wydruku lub przesłania informacji albo przeniesienia jej na odpowiedni powszechnie stosowany nośnik informacji ${ }^{75}$. Warto zauważyć, że jeśli w wyniku udostępniania informacji publicznej podmiot zobowiązany do jej udostępnienia poniósł dodatkowe koszty związane ze wskazanym we wniosku sposobem udostępnienia, to może pobrać od wnioskodawcy opłatę wysokości odpowiadającej tym kosztom. O wysokości opłaty zobowiązany jest powiadomić w terminie 14 dni od dnia złożenia wniosku o udostępnienie informacji publicznej ${ }^{76}$.

Prawo prasowe nie przewiduje prawa udziału dziennikarzy w obradach jakichkolwiek ciał kolegialnych organizacji społecznych. Konstytucja, we wspomnianym art. 61 ust. 2, gwarantuje dziennikarzom, podobnie jak wszystkim obywatelom, jedynie wstęp na posiedzenia kolegialnych organów władzy publicznej, pochodzących z wyborów. Prawa tego nie można rozszerzać na obrady innych ciał kolegialnych, takich jak: związki zawodowe, partie polityczne, organizacje społeczne. NSA postanowieniem z 13 maja 1991 r. (a więc przed uchwaleniem i wejściem w życie Konstytucji z 1997 r.) odrzucając skargę redaktora naczelnego, złożoną w oparciu o art. 4 ust. 3 i 4 pr.pr. - a więc jeszcze przed zmianami prawa prasowego dokonanymi ustawą o dostępie do informacji publicznej - na usunięcie dziennikarza z sali obrad związku zawodowego, stwierdził, iż regulacja prawa prasowego dopuszczająca skargę do NSA na odmowę udzielania prasie informacji jest regulacją o charakterze szczególnym i jako taka nie podlega wykładni rozszerzającej. W treści uzasadnienia postanowienia wyraził pogląd, że usunięcie dziennikarza z sali obrad może być traktowane jako uniemożliwienie prasie ustawowo zagwarantowanej swobody zbierania informacji, w sytuacji gdy dziennikarza usuwa się z miejsc, które z natury rzeczy służą uzyskiwaniu informacji. Jako miejsca takie wskazał jawne obrady organów zobowiązanych do udzielania prasie informacji oraz konferencje prasowe. Doszedł jednak do przekonania, że obrady statutowych organów związków zawodowych należą do działalności wewnątrzzwiązkowej, natomiast obowiązek udzielania informacji w odniesieniu do związków zawodowych dotyczy jedynie zleconych im

\footnotetext{
75 Art. 12 ust. 2 pkt 1 i 2 u.d.i.p.

76 Art. 15 u.d.i.p.
} 
zadań w sferze administracji państwowej oraz innej, podobnej działalności publicznej - art. 4 ust. 5 pr.pr. ${ }^{77} \mathrm{~W}$ świetle obowiązujących w chwili orzekania przepisów prawnych nie sposób odmówić słuszności rozumowaniu NSA zawartemu w powołanym postanowieniu. Nie sposób oprzeć się wrażeniu, iż obecny, restrykcyjny system regulujący zasady dostępu do informacji, zakorzeniony w ubiegłej epoce politycznej, ograniczając dostęp dziennikarza do informacji, pozwalając na jego usuwanie z sal obrad związków zawodowych, partii politycznych, organizacji społecznych, $\mathrm{w}$ istocie rzeczy sprzeczny jest z konstytucyjną zasadą jawności życia publicznego oraz wolności prasy i innych środków przekazu ${ }^{78}$. Nieznane są powody, dla których dotychczas zgłoszone projekty prawa prasowego petryfikują dotychczasowe uregulowania dość wąsko rozumiejące prawo do informacji. Wysoce aktualny jest przy tym pogląd, że usunięcie dziennikarza z sali obrad może być traktowane jako uniemożliwienie prasie ustawowo zagwarantowanej swobody zbierania informacji, w sytuacji gdy dziennikarza usuwa się z miejsc, które z natury rzeczy służą uzyskiwaniu informacji.

Ograniczenia w zakresie dostępu do informacji o działalności organów władzy publicznej oraz osób pełniących funkcje publiczne mogą wynikać z treści art. 31 ust. 3 Konstytucji, oczywiście przy założeniu modyfikacji, jaką przynosi art. 61 ust. 3 Konstytucji. Podkreślić należy, że ograniczenie prawa do tych informacji może wystapić wyłącznie ze względu na określoną w ustawach ochronę wolności i praw innych osób oraz podmiotów gospodarczych, a także - ze względu na potrzebę ochrony porządku publicznego, bezpieczeństwa lub ważnego interesu gospodarczego państwa. Wypada przy tym zauważyć, że ustawa o dostępie do informacji publicznej nie wskazuje podstaw odmowy tych informacji, zaznaczając jedynie w treści art. 5 , że prawo do informacji publicznej podlega ograniczeniu w zakresie i na zasadach określonych w przepisach o ochronie informacji niejawnych oraz o ochronie innych tajemnic ustawowo chronionych ${ }^{79}$. Kolejną barierą ograniczającą prawo do informacji publicznej jest wzgląd na prywatność osoby fizycznej lub tajemnicę przedsiębiorcy. Ograniczenie to nie może jednak dotyczyć informacji o osobach pełniących funkcje publiczne - jeśli informacje te mają związek z pełnieniem tych funkcji, w tym $z$ warunkami ich powierzenia i wykonywania.

\footnotetext{
77 Por. postanowienie NSA z 13 maja 1992 r., SA Wr 512/92.

78 Art. 14 Konstytucji 1997 r.

79 Art. 5 ust. 1 u.d.i.p.
} 
Oczywiście, osoba fizyczna lub przedsiębiorca mogą zrezygnować z przysługującego im prawa. Informacje o sprawach rozstrzyganych w toczących się postępowaniach sądowych (karnym, cywilnym, administracyjnym) udostępniane są według zasad określonych w odpowiednich kodeksach postępowania. W nich też należy poszukiwać zasad dostępu do odpowiednich akt sprawy. W ustawie o dostępie do informacji publicznej stwierdzono jedynie, że nie można ograniczać dostępu do informacji w takich sprawach, w których postępowanie dotyczy władz publicznych lub innych podmiotów wykonujących zadania publiczne albo osób pełniących funkcje publiczne w zakresie tych zadań lub funkcji ${ }^{80}$. Wypada więc skonstatować, że ustawa o dostępie do informacji publicznej, której przepisy należy odczytywać w nawiązaniu do odpowiednich norm kodeksów postępowania, stara się ograniczyć możliwości odmowy informacji o toczących się postępowaniach dotyczących osób pełniących funkcje publiczne lub o sprawach, które związane były z działalnością władz publicznych lub innych podmiotów wykonujących zadania publiczne. Konstatując powyższe, wypada jednak zauważyć, że w praktyce, pierwszeństwo przed wspomnianymi uregulowaniami ma wzgląd na tajemnicę chronioną ustawą. W wielu przypadkach te kwestie legły u podstaw ograniczeń w dostępie do akt toczących się spraw - nie mówiąc już o możliwości udziału w toczących się postępowaniach. Przykładem tego typu ograniczeń mogą być postępowania w tzw. sprawach „lustracyjnych” prowadzone w myśl nieobowiązującej już ustawy z 11 kwietnia 1997 r., o ujawnieniu pracy lub służby $\mathrm{w}$ organach bezpieczeństwa państwa lub współpracy z nimi w latach 1944-1990 osób pełniących funkcje publiczne ${ }^{81}$. Konstatacja ta znajduje potwierdzenie $\mathrm{w}$ wyroku NSA w Warszawie $\mathrm{z}$ dnia 15 lipca 2003 r. $^{82}$, w którym stwierdzono, iż z przepisów ustawy z 18 grudnia $1998 \mathrm{r}$. o Instytucie Pamięci Narodowej - Komisji Ścigania Zbrodni Przeciwko Narodowi Polskiemu, wynika reguła, że udostępnienie dokumentów organów bezpieczeństwa państwa wskazanych w ustawie może się odbywać jedynie na podstawie ustawy o Instytucie Pamięci Narodowej.

Ograniczenia ze względu na ochronę porządku publicznego lub bezpieczeństwa państwa mogą być wprowadzone jedynie na zasadach określonych w ustawie. Podstawową ustawą, która reguluje kwestie dostępu

\footnotetext{
80 Art. 5 ust. 3 u.d.i.p.

81 T.j. Dz. U. 1999, Nr 42, poz. 428.

82 II SA 1214/03, „Monitor Prawniczy” 2003, nr 19, s. 868.
} 
jest ustawa z dnia 22 stycznia 1999 r. o ochronie informacji niejawnych ${ }^{83}$. Poza wspomnianą ustawą znalazły się inne tajemnice chronione ustawą, w pierwszym rzędzie te mające charakter tajemnic zawodowych, z których jedną jest tajemnica dziennikarska.

Wypada zauważyć, że ustawa o dostępie do informacji publicznej zawiera także przepis karny grożący odpowiedzialnością temu, kto wbrew ciążącemu na nim obowiązkowi nie udostępnia informacji publicznej. Dobrem chronionym jest prawo do informacji publicznej. Przestępstwo nieudostępnienia informacji publicznej jest przestępstwem indywidualnym. Sprawcą jego może być jedynie ten, kto wbrew ciążącemu na nim obowiązkowi udostępnienia informacji - informacji takiej nie udostępnił. Obowiązek udostępnienia informacji może wynikać z ustawy bądź z umowy o pracę. Zakres podmiotów zobowiązanych do udostępniania informacji określa generalnie art. 4 ust. 1 u.d.i.p. Zwrócić uwagę należy na to, że mogą to być w praktyce także osoby, którym powierzono udostępnianie informacji publicznej. Z całą pewnością obowiązek ten nie spoczywa i nie może spoczywać na wszystkich pracownikach danej instytucji. Warto zauważyć, iż ustawodawca, określając stronę podmiotową, użył jedynie sformułowania: „wbrew ciążącemu na nim obowiązkowi”, zamiast częściej spotykanego w kodeksie karnym: „wbrew przepisom ustawy lub przyjętemu na siebie zobowiązaniu". W praktyce oznaczać to musi wyłączenie osób, którym powierzono udostępnianie informacji publicznej w oparciu o umowę zlecenia bądź - co może być rzadziej spotykane umowę o dzieło. Przestępstwo z art. 23 u.d.i.p. popełnić można wyłącznie umyślnie z zamiarem bezpośrednim. Sprawca musi zdawać sobie sprawę $\mathrm{z}$ tego, że nie udostępnia informacji publicznej, mimo że powinien to uczynić. Wbrew stanowisku wyrażonym w literaturze ${ }^{84}$, nie jest możliwe popełnienie występku z art. 23 u.d.i.p. w sposób nieumyślny. Pamiętać należy, że występek można popełnić nieumyślnie, jeżeli ustawa tak stanowi. W tej sytuacji, uznanie, że sprawca może dopuścić się występku nieumyślnie mogłoby mieć miejsce dopiero wówczas, gdyby treść przepisu brzmiała: „kto wbrew ciążącemu na nim obowiązkowi, chociażby nieumyślnie nie udostępnia informacji publicznej”. Czyn zabroniony dyspozycją

83 T.j. Dz. U 2005, Nr 196, poz. 1631; zm. Dz. U. 2006, Nr 104, poz.708; 2006, $\mathrm{Nr}$ 149, poz. 1078; Nr 104, poz. 711; Nr 220, poz. 1600; Nr 218, poz. 1592. O zawartych w treści ustawy ograniczeniach zob. niżej do art. 4.

84 Zob. T. R. Aleksandrowicz, Komentarz do ustawy o dostępie do informacji publicznej, Warszawa 2002, s. 169. 
art. 23 u.d.i.p. może być popełniony zarówno w postaci dokonania, jak i usiłowania. Oczywiście, przygotowanie do takiego czynu nie jest karalne. Jak się wydaje, możliwe są wszystkie postaci sprawstwa, o których mowa w art. $18 \S 1$ k.k., a więc w postaci podżegania i pomocnictwa.

Warto pamiętać, że przestępstwa przeciwko ochronie informacji zostały objęte rozdz. XXXIII kodeksu karnego, przy czym szczególnie niebezpieczne w płaszczyźnie dostępu do informacji publicznej mogą być czyny: godzące w tajemnicę państwową (art. 265 k.k., np. poprzez jej ujawnienie wbrew przepisom ustawy lub wykorzystanie), polegające na ujawnieniu tajemnicy zawodowej, funkcyjnej lub służbowej (art. 266 k.k.); naruszające cudzą tajemnicę (art. 267 k.k.); polegające na niszczeniu zapisu informacji i niszczeniu informacji komputerowych (art. 268 i 269 k.k.). Problemy dostępu do informacji publicznej mogą dotykać także przestępstwa z rozdz. XXXIV kodeksu karnego, czyli przestępstwa przeciwko wiarygodności dokumentów, a mianowicie: fałszowanie dokumentów (art. 270 k.k.), poświadczanie nieprawdy (art. 271 k.k.) i wyłudzenie poświadczenia nieprawdy (art. 272 k.k.), użycie dokumentów poświadczających nieprawdę (art. 273 k.k.), niszczenie, uszkadzanie, ukrywanie dokumentów (art. 276 k.k.) $)^{85}$.

Prawo dostępu do informacji publicznej, w tym także prawo dziennikarza do takiej informacji, nie ma jednak - jak słusznie stwierdzono w judykaturze - charakteru absolutnego i podlega ustawowym ograniczeniom. Z obowiązku udzielenia prasie informacji o swojej działalności nie można wyprowadzać istnienia prawnego obowiązku udostępniania treści umów cywilnych, których stronami (stroną) są także inne podmioty ${ }^{86}$. Podmioty wskazane w art. 4 ust. 1 pr.pr. mają obowiązek udzielania prasie informacji o swej działalności - z wyjątkiem odmowy motywowanej potrzebą ochrony tajemnicy oraz z uwagi na potrzebę ochrony prawa do prywatności. Na żądanie redaktora naczelnego pisemną odmowę udzielenia informacji doręcza się redakcji w terminie trzech dni ze wskazaniem jej powodów, a odmowę lub niezachowanie określonych wymogów można zaskarżyć w terminie miesiąca. Uwzględniając określony w art. 61 ust. 2 Konstytucji RP zakres prawa do informacji, należy stwierdzić, że podmioty te obowiązane są także do zapewnienia prasie dostępu do dokumentów

85 Zob. Kodeks karny. Część szczególna, red. A. Wąsek, t. II, Warszawa 2004, s. $395-639$.

${ }^{86}$ Zob. wyrok NSA w Łodzi z 25 lipca 2002 r., II SA/Łd 951/02; „Monitor Prawniczy" 2002, nr 18, s. 819. 
łączących się z ich działalnością, jeżeli nie ma ustawowych wyłączeń ze względu na ochronę wolności i praw innych osób i podmiotów gospodarczych oraz ochronę porządku publicznego, bezpieczeństwa lub ważnego interesu państwa (art. 61 ust. 3 Konstytucji). Realizacja uprawnień prasy do uzyskania informacji następuje więc przez podanie jej określonej wiadomości lub udostępnienie w stosownym trybie żądanych dokumentów. Uprawnienia te nie mogą służyć wymuszaniu na wymienionych podmiotach nowych zachowań dotyczących ich merytorycznej działalności. Prasa może na nią wpływać w ramach krytyki prasowej jako wyodrębnionej konstrukcji $\mathrm{w}$ art. 6 Prawa prasowego oraz art. 248 i 251 k.p.a. ${ }^{87}$

Podzielić należy pogląd, zawarty w wielu orzeczeniach NSA, co do tego, iż obowiązkiem władz samorządowych jest podanie prasie informacji o wysokości zarobków burmistrza, jego zastępców i skarbnika. Kwestia ta dość długo była sporna w doktrynie, jak i judykaturze. Przeciwko ujawnianiu takich danych jednoznacznie wypowiedział się Sąd Najwyższy w uchwale składu siedmiu sędziów Sądu Najwyższego z 16 lipca 1993 r. (PZP 28/93), uznając, że ujawnienie przez pracodawcę bez zgody pracownika wysokości jego wynagrodzenia może stanowić naruszenie dobra osobistego w rozumieniu art. $23 \mathrm{i}$ art. 24 k.c. Z poglądem tym polemizował J. Boć, stwierdzając, iż nie ma jakichkolwiek racji prawnych, dla których obywatel nie mógłby żądać informacji o zarobkach określonej kategorii organów i funkcjonariuszy władzy publicznej ${ }^{88}$. Stanowisko to podzielił wielokrotnie NSA, stwierdzając, że ochrona, o jakiej mowa w art. 23 i art. 24 k.c., objęta jest tylko dziedzina życia osobistego i prywatnego człowieka. Ochrona ta, według NSA, nie obejmuje zatem działalności publicznej jakiejś osoby ani też sfery działań czy zachowań, które ogólnie są pojmowane jako osobiste lub prywatne, jeżeli te działania lub zachowania wiążą się ściśle z działalnością publiczną. Tym samym, zdaniem NSA, wynagrodzenie członków zarządu gminy nie należy wyłącznie do sfery prywatności osób piastujących te stanowiska, gdyż wiąże się z ich funkcją publiczną. Tym samym organ gminy nie może zasadnie odmówić dziennikarzowi udzielenia informacji o wysokości wynagrodzenia za pracę osób piastujących takie stanowiska. Za podaniem prasie takiej informacji, zdaniem NSA, przemawia zasada jawności życia publicznego, z której wynika, że społeczność lokalna ma prawo wiedzieć, jak korzysta się ze środków

87 Zob. wyrok NSA z 19 września 2001 r., LEX nr 54202.

88 Por. Konstytucje Rzeczypospolitej, red. J. Boć, s. 115. 
pieniężnych gminy i jak kształtuje się wynagrodzenie wypłacane z tych środków osobom zajmującym stanowiska w strukturze samorządu terytorialnego ${ }^{89}$. W orzecznictwie NSA podkreślono także, iż skoro Rada Ministrów w drodze rozporządzenia określa zasady wynagrodzenia, które wraz z tabelami miesięcznych stawek wynagrodzenia zasadniczego oraz stawek dodatku funkcyjnego są publikowane w Dzienniku Ustaw, to nie ma przeszkód, aby pokazać, jak się ma konkretyzacja zasad i stawek ustalonych przez Radę Ministrów ${ }^{90}$.

Poglądy na możliwość ujawnienia wysokości wynagrodzenia za pracę przeszły dość znamienną ewolucję. Sąd Najwyższy w uchwale, w składzie siedmiu sędziów, z dnia 16 lipca 1993 r. ${ }^{91}$ zajął stanowisko, że ujawnienie przez pracodawcę bez zgody pracownika wysokości jego wynagrodzenia za pracę może stanowić naruszenie dobra osobistego w rozumieniu art. 23 i art. 24 k.c. W kilka lat później w wyroku z 11 stycznia 1996 r. ${ }^{92}$ Sąd Najwyższy, powołując się na wspomnianą wyżej uchwałę, stwierdził jednak, że zakaz ujawnienia wysokości wynagrodzenia za pracę, ze względu na zakaz naruszania dóbr osobistych, będzie usprawiedliwiony tylko wówczas, gdy taką informację można zaliczyć do sfery prywatności pracownika. Zauważył też, że dopuszczalne jest publikowanie informacji oraz danych dotyczących prywatnej sfery życia bez zgody danej osoby, jeżeli wiąże się to bezpośrednio z jej działalnością publiczną. Za możliwością ujawniania informacji o wysokości zarobków dość jednoznacznie wypowiadał się Naczelny Sąd Administracyjny w przywołanych wyżej wyrokach, w szczególności w wyroku z 6 maja 1997 r. i 8 lutego 1993 r. Podzielić należy także pogląd wyrażony w uzasadnieniu wyroku NSA w Warszawie z 22 kwietnia 1999 r., iż odmowa udzielenia informacji musi mieć oparcie w konkretnej normie ustawowej, przy czym gdyby w ujawnionych dokumentach znalazły się informacje mogące naruszyć chronione ustawą prawa różnych podmiotów, to dane te przed udostępnieniem dokumentów winny być wyłączone (I SA 2274/98).

89 Wyrok ośrodka NSA we Wrocławiu z 6 maja 1997 r., II SA/Wr 929/96, ONSA 1998, nr 2 poz. 54; wyrok NSA w Warszawie z 8 lutego 1993 r., I SA 1254/92; wyrok NSA w Warszawie z 7 sierpnia 1998 r. I SA 559/98.

90 Wyrok NSA w Warszawie z 8 lutego 1993 r. I SA 1254/92.

91 I PZP 28/95, „Prawa i Zabezpieczenie Społeczne” 1984, nr 1.

92 III ARN 57/95 OSNAPiUS 1996 r., nr 13, poz. 179. 


\section{Summary}

Article 3a, introduced to press law, is of immense importance, which is underestimated in practice. In respect of the press access to public information, it makes a journalist's rights equal with the rights of any subject who can apply for public information. The legislator, who amended the press law, failed to define the notion of 'public information' referred to in the above-mentioned regulation. 